\title{
LEVEL II SCOUR ANALYSIS FOR BRIDGE 16 (BURKTH00070016) on TOWN HIGHWAY 7, crossing DISH MILL BROOK, BURKE, VERMONT
}

Open-File Report 97-758

Prepared in cooperation with

VERMONT AGENCY OF TRANSPORTATION

and

FEDERAL HIGHWAY ADMINISTRATION

U.S. Department of the Interior

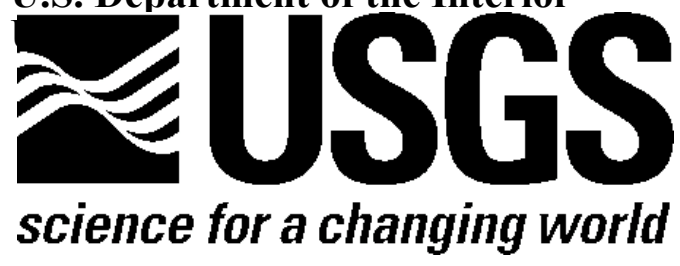




\section{LEVEL II SCOUR ANALYSIS FOR BRIDGE 16 (BURKTH00070016) on TOWN HIGHWAY 7, crossing DISH MILL BROOK, BURKE, VERMONT \\ By RONDA L. BURNS AND TIM SEVERANCE}

U.S. Geological Survey Open-File Report 97-758

Prepared in cooperation with

VERMONT AGENCY OF TRANSPORTATION and

FEDERAL HIGHWAY ADMINISTRATION

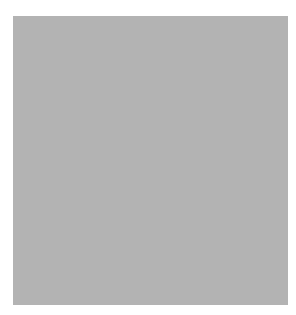




\title{
U.S. DEPARTMENT OF THE INTERIOR BRUCE BABBITT, Secretary
}

\author{
U.S. GEOLOGICAL SURVEY \\ Mark Schaefer, Acting Director
}

For additional information write to:

District Chief

U.S. Geological Survey 361 Commerce Way

Pembroke, NH 03275-3718
Copies of this report may be purchased from:

U.S. Geological Survey

Branch of Information Services

Open-File Reports Unit

Box 25286

Denver, CO 80225-0286 


\section{CONTENTS}

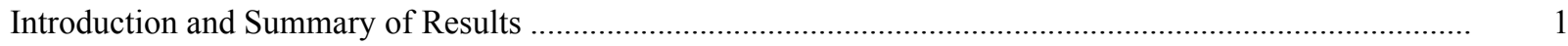

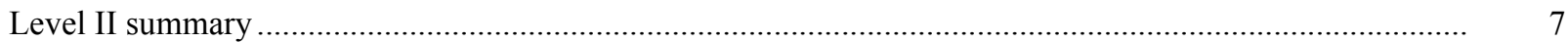

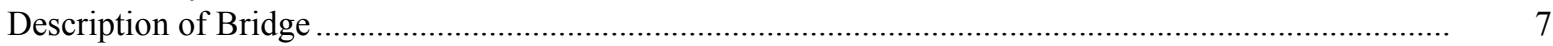

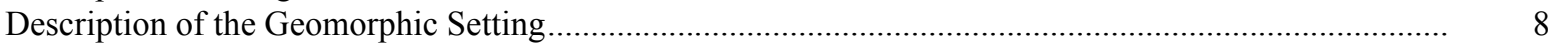

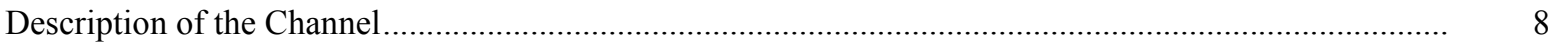

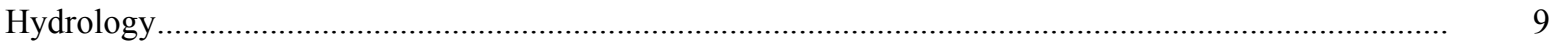

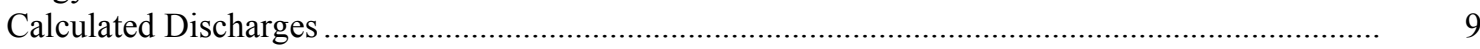

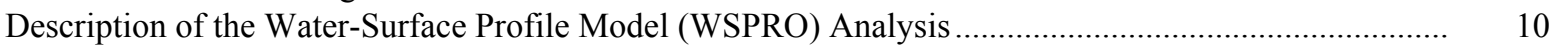

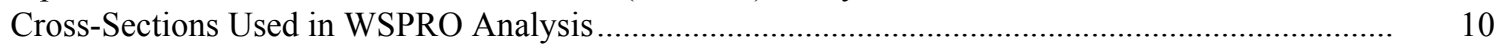

Data and Assumptions Used in WSPRO Model ...................................................................... 11

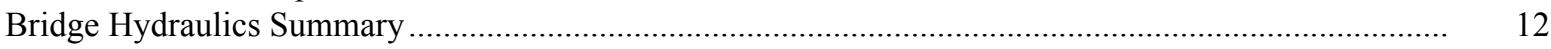

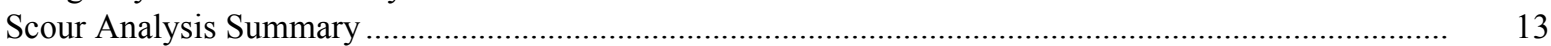

Special Conditions or Assumptions Made in Scour Analysis ...................................................... 13

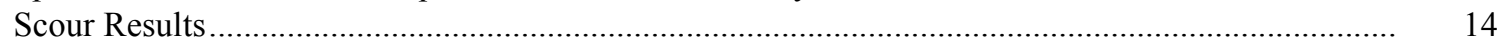

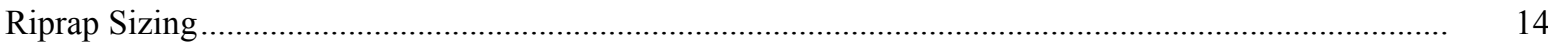

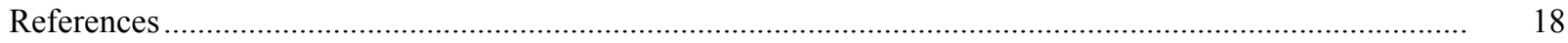

Appendixes:

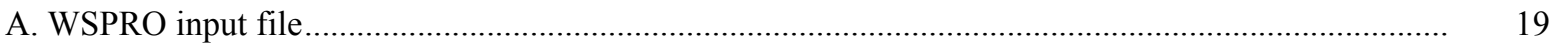

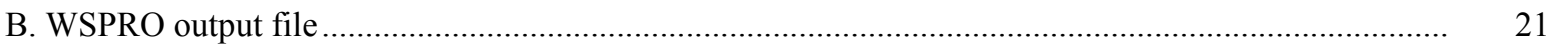

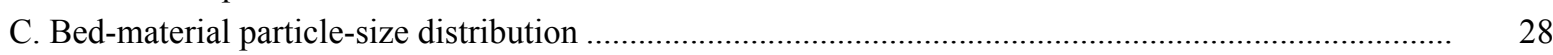

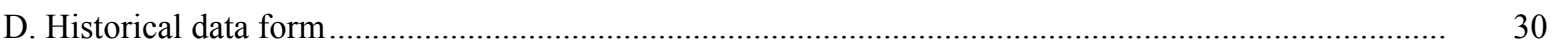

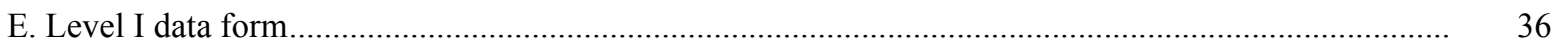

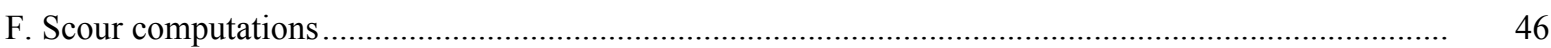

\section{FIGURES}

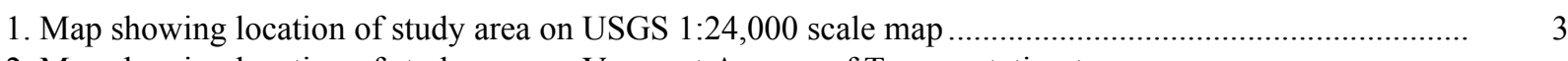

2. Map showing location of study area on Vermont Agency of Transportation town
highway map

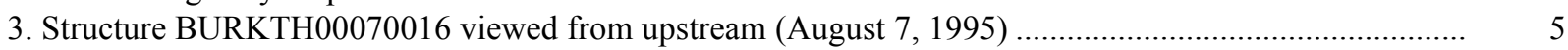

4. Downstream channel viewed from structure BURKTH00070016 (August 7, 1995) ............................ 5

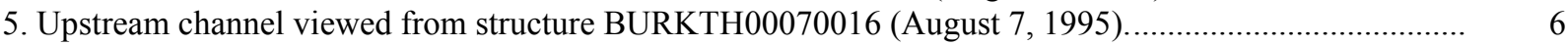

6. Structure BURKTH00070016 viewed from downstream (August 7, 1995)........................................... 6

7. Water-surface profiles for the 100- and 500-year discharges at structure BURKTH00070016 on Town Highway 7, crossing Dish Mill Brook,

Burke, Vermont.

8. Scour elevations for the 100- and 500-year discharges at structure

BURKTH00070016 on Town Highway 7, crossing Dish Mill Brook,

Burke, Vermont.

(3)

5

5

(1)

(

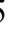

\section{TABLES}

1. Remaining footing/pile depth at abutments for the 100-year discharge at structure

BURKTH00070016 on Town Highway 7, crossing Dish Mill Brook,

Burke, Vermont

2. Remaining footing/pile depth at abutments for the 500-year discharge at structure

BURKTH00070016 on Town Highway 7, crossing Dish Mill Brook,

Burke, Vermont.. 


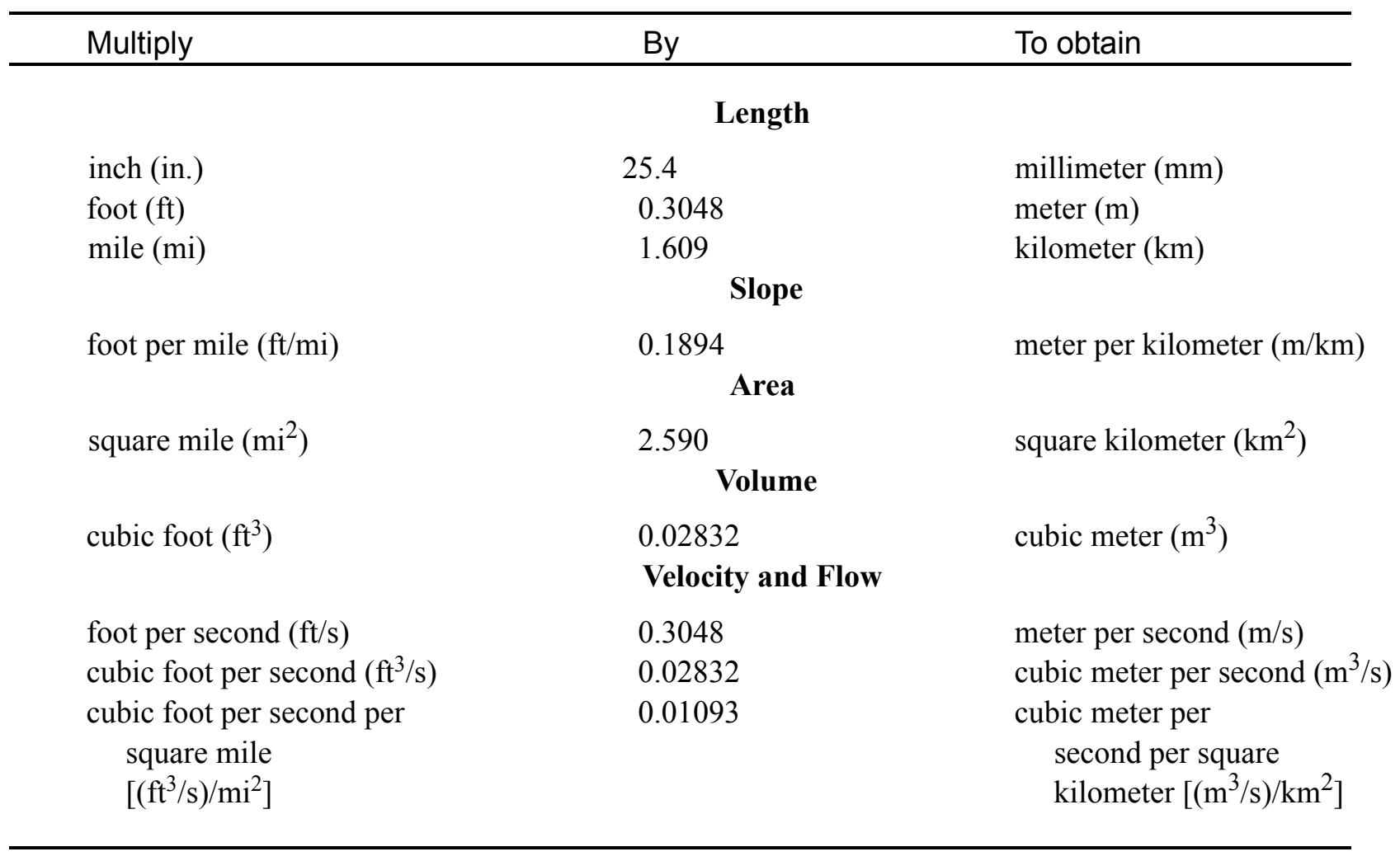

\section{OTHER ABBREVIATIONS}

$\begin{array}{lrlr}\mathrm{BF} & \text { bank full } & \text { LWW } & \text { left wingwall } \\ \mathrm{cfs} & \text { cubic feet per second } & \text { MC } & \text { main channel } \\ \mathrm{D}_{50} & \text { median diameter of bed material } & \text { RAB } & \text { right abutment } \\ \mathrm{DS} & \text { downstream } & \text { RABUT } & \text { face of right abutment } \\ \mathrm{elev} & \text { elevation } & \text { RB } & \text { right bank } \\ \mathrm{f} / \mathrm{p} & \text { flood plain } & \text { ROB } & \text { right overbank } \\ \mathrm{ft}^{2} & \text { square feet } & \text { RWW } & \text { right wingwall } \\ \mathrm{ft} / \mathrm{ft} & \text { feet per foot } & \text { TH } & \text { town highway } \\ \mathrm{JCT} & \text { junction } & \text { UB } & \text { under bridge } \\ \mathrm{LAB} & \text { left abutment } & \text { US } & \text { upstream } \\ \mathrm{LABUT} & \text { face of left abutment } & \text { USGS } & \text { United States Geological Survey } \\ \mathrm{LB} & \text { left bank } & \text { VTAOT Vermont Agency of Transportation } \\ \mathrm{LOB} & \text { left overbank } & \text { WSPRO } & \text { water-surface profile model }\end{array}$

In this report, the words "right" and "left" refer to directions that would be reported by an observer facing downstream. Sea level: In this report, "sea level" refers to the National Geodetic Vertical Datum of 1929-- a geodetic datum derived from a general adjustment of the first-order level nets of the United States and Canada, formerly called Sea Level Datum of 1929.

In the appendices, the above abbreviations may be combined. For example, USLB would represent upstream left bank. 


\title{
LEVEL II SCOUR ANALYSIS FOR BRIDGE 16 (BURKTH00070016) ON TOWN HIGHWAY 7, CROSSING DISH MILL BROOK, BURKE, VERMONT
}

\author{
By Ronda L. Burns and Tim Severance
}

\section{INTRODUCTION AND SUMMARY OF RESULTS}

This report provides the results of a detailed Level II analysis of scour potential at structure BURKTH00070016 on Town Highway 7 crossing Dish Mill Brook, Burke, Vermont (figures 1-8). A Level II study is a basic engineering analysis of the site, including a quantitative analysis of stream stability and scour (U.S. Department of Transportation, 1993). Results of a Level I scour investigation also are included in Appendix E of this report. A Level I investigation provides a qualitative geomorphic characterization of the study site. Information on the bridge, gleaned from Vermont Agency of Transportation (VTAOT) files, was compiled prior to conducting Level I and Level II analyses and is found in Appendix D.

The site is in the White Mountain section of the New England physiographic province in northeastern Vermont. The $6.0-\mathrm{mi}^{2}$ drainage area is in a predominantly rural and forested basin. In the vicinity of the study site, the surface cover is forest except on the left bank upstream which is brushland.

In the study area, Dish Mill Brook has an incised, sinuous channel with a slope of approximately $0.04 \mathrm{ft} / \mathrm{ft}$, an average channel top width of $40 \mathrm{ft}$ and an average bank height of $6 \mathrm{ft}$. The channel bed material ranges from sand to boulder with a median grain size $\left(\mathrm{D}_{50}\right)$ of $94.1 \mathrm{~mm}(0.309 \mathrm{ft})$. The geomorphic assessment at the time of the Level I and Level II site visit on August 7, 1995, indicated that the reach was stable.

The Town Highway 7 crossing of Dish Mill Brook is a 28-ft-long, two-lane bridge consisting of one 24-foot steel-beam span (Vermont Agency of Transportation, written communication, March 24, 1995). The opening length of the structure parallel to the bridge face is $24.8 \mathrm{ft}$. The bridge is supported by vertical, concrete abutments with wingwalls. The channel is skewed approximately 35 degrees to the opening while the computed openingskew-to-roadway is 35 degrees. 
A scour hole $1.0 \mathrm{ft}$ deeper than the mean thalweg depth was observed along the left and right abutments during the Level I assessment. In front of the upstream and downstream left wingwalls the scour depth was only $0.5 \mathrm{ft}$, while in front of the downstream right wingwall it was $0.75 \mathrm{ft}$ and in front of the upstream right wingwall it was $0.3 \mathrm{ft}$. The scour countermeasures at the site include type- 1 stone fill (less than 12 inches diameter) at the downstream end of the right abutment and along the downstream right wingwall. Type- 2 stone fill (less than 36 inches diameter) is along the upstream left bank, the upstream and downstream left wingwalls, and at the upstream end of the upstream right wingwall. Additional details describing conditions at the site are included in the Level II Summary and Appendices D and E.

Scour depths and recommended rock rip-rap sizes were computed using the general guidelines described in Hydraulic Engineering Circular 18 (Richardson and others, 1995) for the 100- and 500-year discharges. In addition, the incipient roadway-overtopping discharge is determined and analyzed as another potential worst-case scour scenario. Total scour at a highway crossing is comprised of three components: 1) long-term streambed degradation; 2) contraction scour (due to accelerated flow caused by a reduction in flow area at a bridge) and; 3 ) local scour (caused by accelerated flow around piers and abutments). Total scour is the sum of the three components. Equations are available to compute depths for contraction and local scour and a summary of the results of these computations follows.

Contraction scour for all modelled flows ranged from 0.0 to $0.5 \mathrm{ft}$. The worst-case contraction scour occurred at the 500-year discharge. Abutment scour ranged from 6.7 to $9.3 \mathrm{ft}$. The worst-case abutment scour occurred at the 500-year discharge for the left abutment and at the incipient road-overtopping discharge for the right abutment. Additional information on scour depths and depths to armoring are included in the section titled "Scour Results". Scoured-streambed elevations, based on the calculated scour depths, are presented in tables 1 and 2. A cross-section of the scour computed at the bridge is presented in figure 8. Scour depths were calculated assuming an infinite depth of erosive material and a homogeneous particle-size distribution.

It is generally accepted that the Froehlich equation (abutment scour) gives "excessively conservative estimates of scour depths" (Richardson and others, 1995, p. 47). Usually, computed scour depths are evaluated in combination with other information including (but not limited to) historical performance during flood events, the geomorphic stability assessment, existing scour protection measures, and the results of the hydraulic analyses. Therefore, scour depths adopted by VTAOT may differ from the computed values documented herein. 


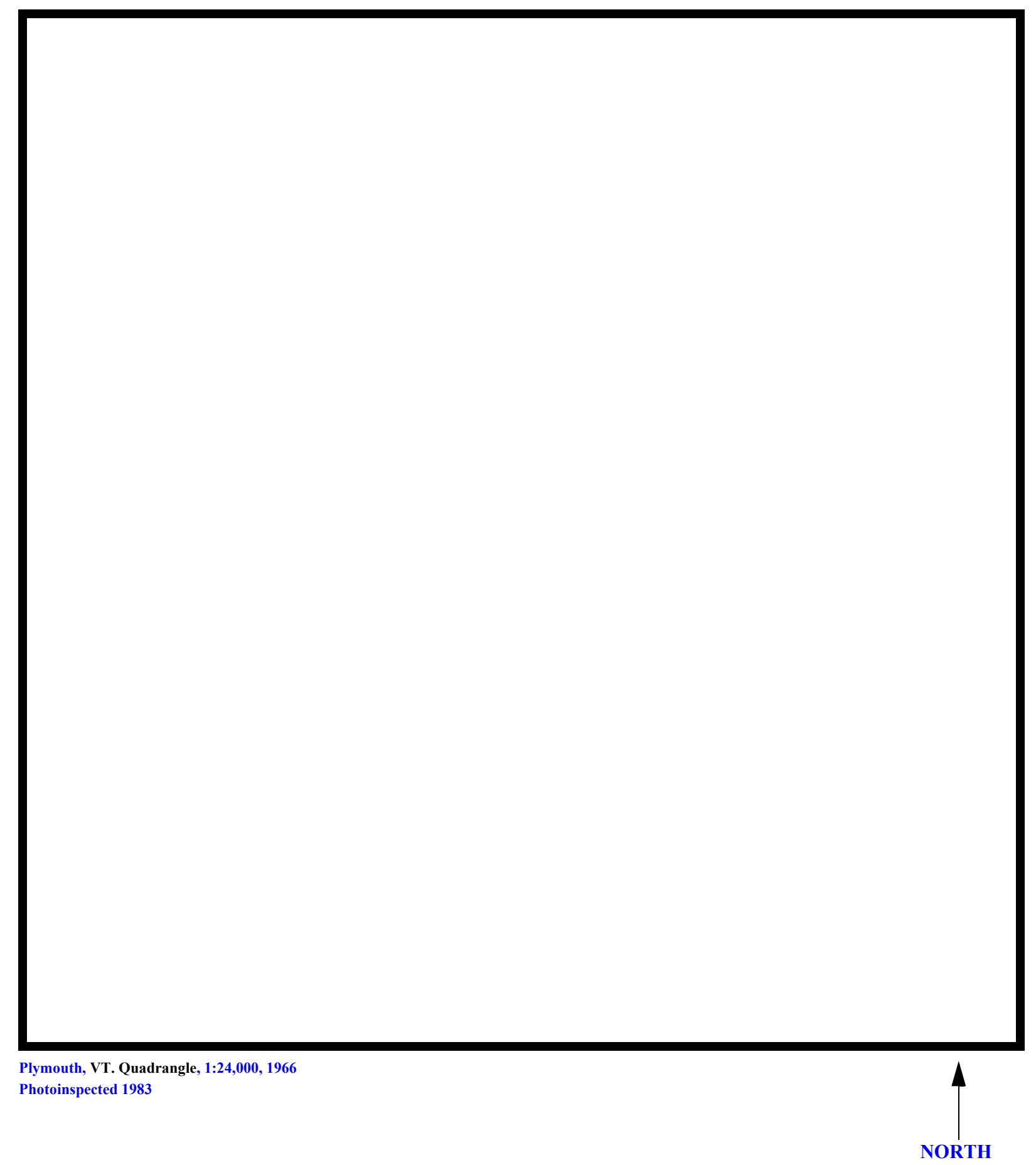

Figure 1. Location of study area on USGS 1:24,000 scale map. 
Figure 2. Location of study area on Vermont Agency of Transportation town highway map. 

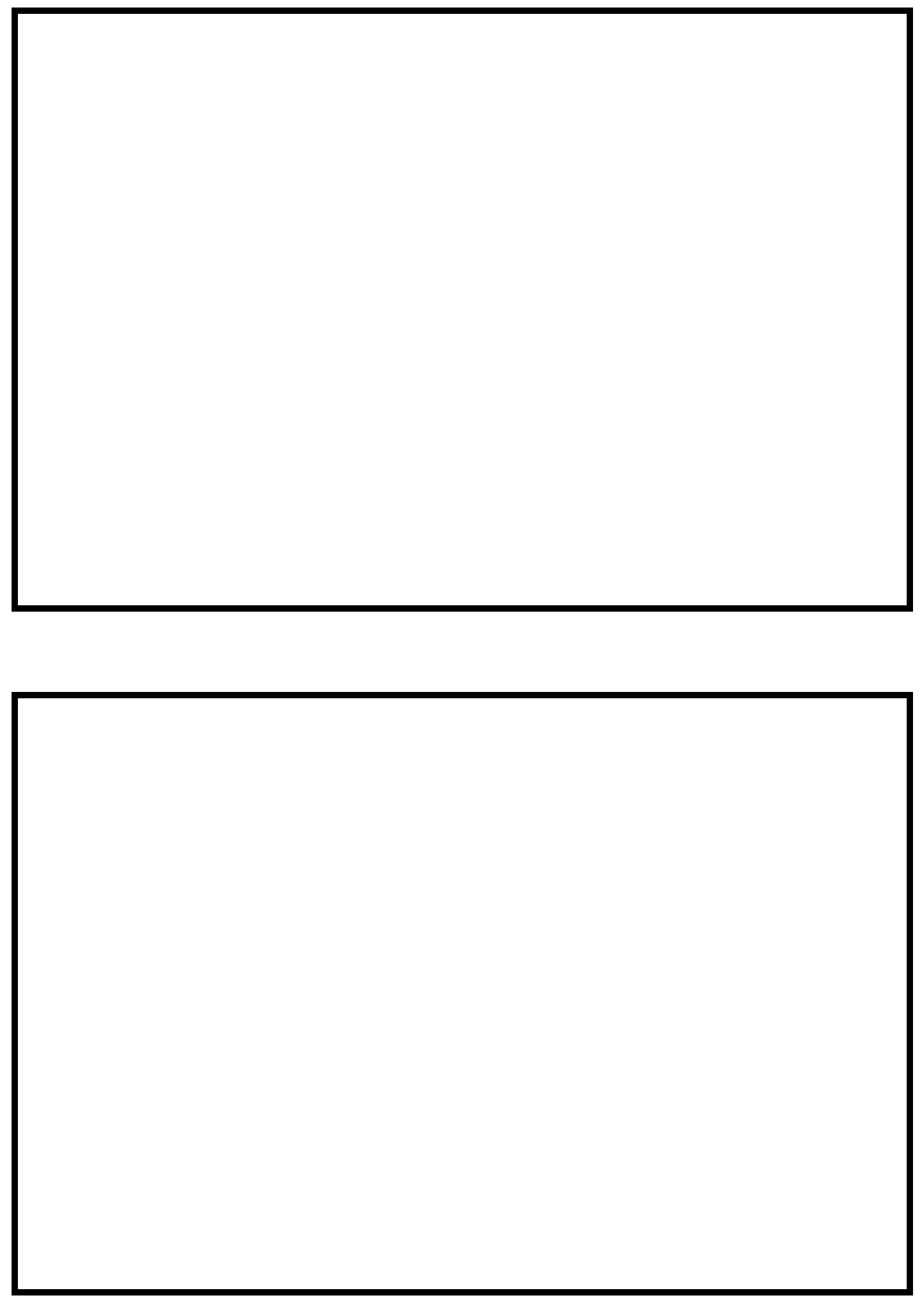

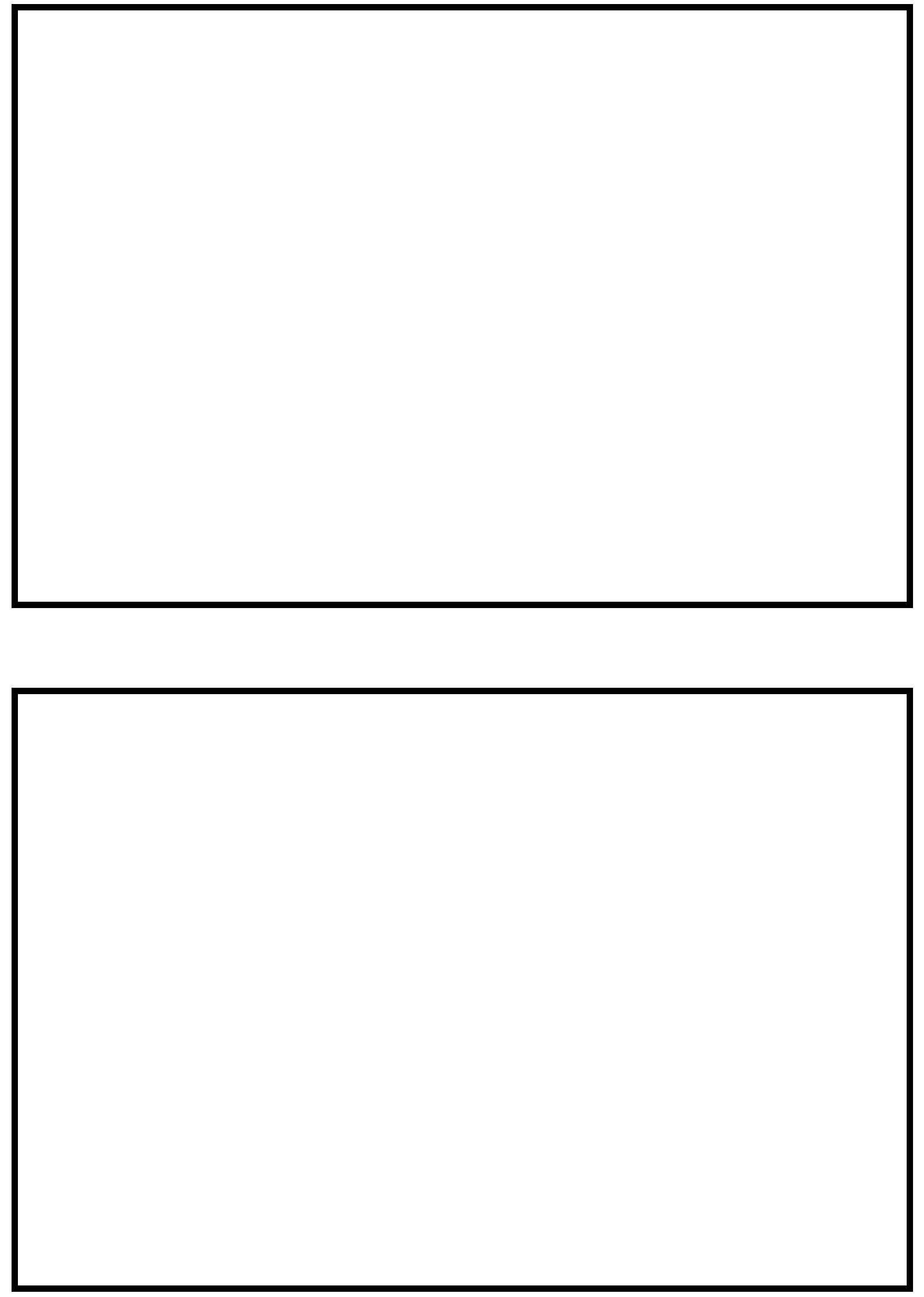


\section{LEVEL II SUMMARY}

\begin{tabular}{llllll} 
Structure Number & \multicolumn{2}{c}{ BURKTH0070016 } & Stream & \multicolumn{3}{l}{ Dish Mill Brook } \\
& Caledonia & Road & TH 7 & District & 7
\end{tabular}

\section{Description of Bridge}

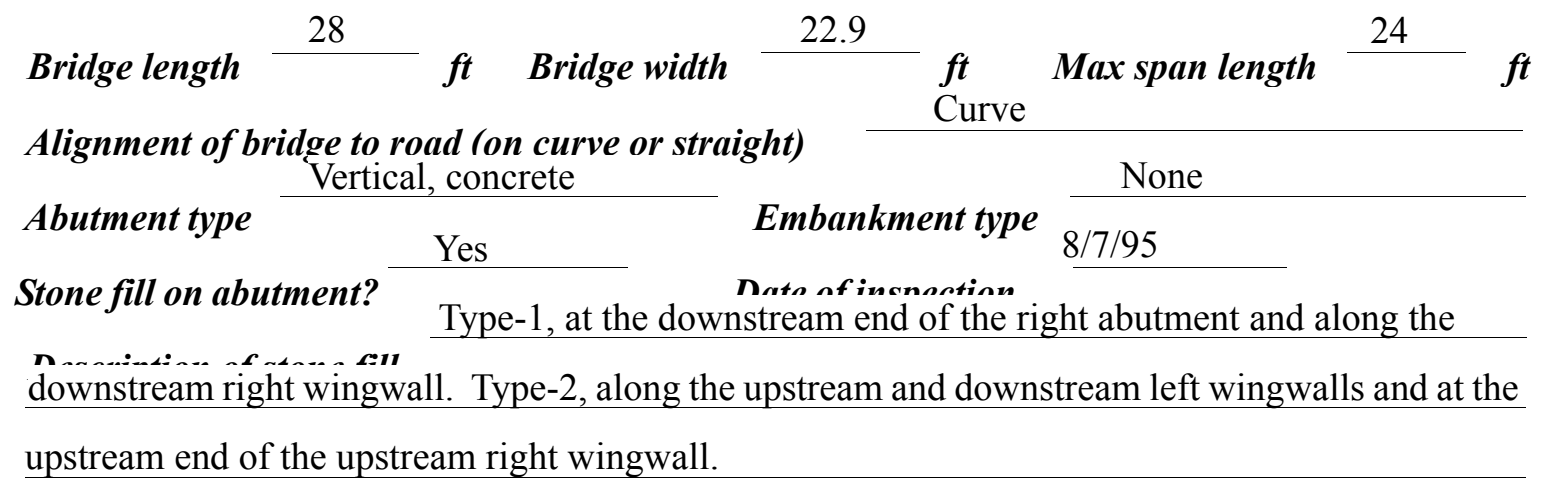

Abutments and wingwalls are concrete. There are 1.0

foot deep scour holes in front of the left and right abutments which extend along their wingwalls.

The right abutment footing is exposed 2.5 feet while the left abutment footing is exposed 1.5 feet.

All four wingwalls also have exposed footings.

$\underline{\text { Yes }}$

Is bridge skewed to flood flow according tyes r.l I survey?

Angle

There is a mild channel bend in the upstream reach which impacts the left bank upstream causing a cut-bank. The flow then impacts the right abutment.

Debris accumulation on bridge at time of Level I or Level II site visit:

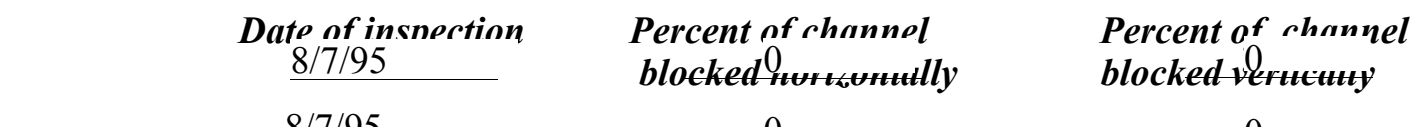

Level I

$8 / 7 / 95$

0

0

Level II Moderate. There is some debris caught on the banks.

Potential for debris

None as of $8 / 7 / 95$. 


\section{Description of the Geomorphic Setting}

General topography The channel is located within a moderate relief valley with steep valley walls on both sides.

Geomorphic conditions at bridge site: downstream (DS), upstream (US)

Date of inspection $\quad 8 / 7 / 95$

DS left: $\quad$ Steep channel bank and irregular overbank to a steep stone pile

DS right: $\quad$ Steep channel bank to a narrow terrace

US left: $\quad$ Steep channel bank to a moderately sloped overbank

US right: $\quad$ Steep valley wall

\section{Description of the Channel}

$\begin{array}{llll}\text { Average top width } & 40 & \text { Average depth } & 6 \\ & \text { Gravel/Cobbles } & \text { Gravel/Cobbles }\end{array}$

Predominant bed material

Bank material Sinuous but stable

with non-alluvial channel boundaries.

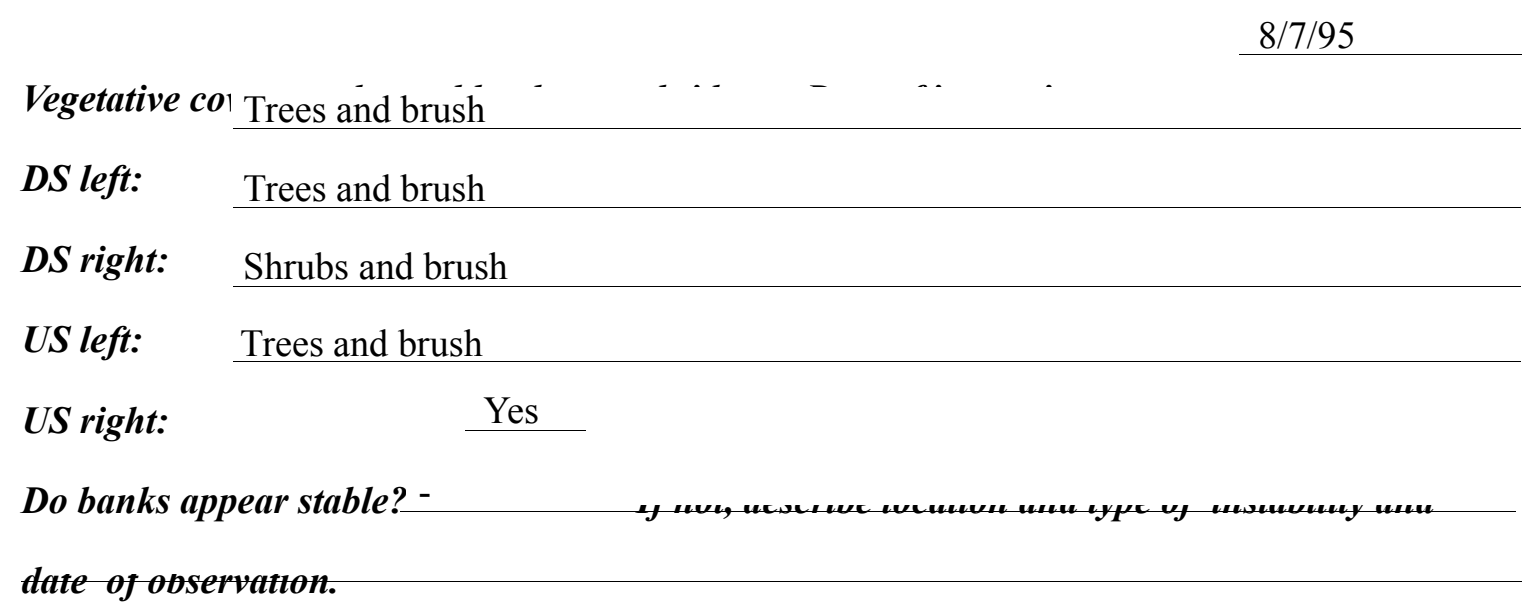

A large boulder in the

center of the channel at the upstream bridge face diverts ambient flow along the left and right Describe any obstructions in channel and date of observation. abutment footings as of $8 / 7 / 95$. 


\section{Hydrology}

Drainage area $\quad \frac{6.0}{m i^{2}}$

Percentage of drainage area in physiographic provinces: (approximate)

Physiographic province/section

New England/White Mountain
Percent of drainage area 100

Is drainage area considered rural or urban? — Rural _ Describe any significant urbanization:

Is there a USGS gage on the stream of interest?

No

USGS gage description
USGS gage number
Gage drainage area

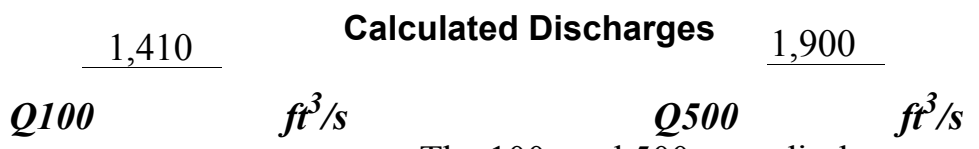

The 100- and 500-year discharges are based on a

drainage area relationship [(6.0/6.35]exp 0.67] with Dish Mill Brook at the confluence with the East Branch Passumpsic River in Burke. The drainage area at the confluence is 6.35 square miles and has flood frequency estimates available in the Flood Insurance Study for the town of Burke (Federal Emergency Management Agency, December 1979). The values used were within a range defined by flood frequency curves developed from several empirical methods (Benson, 1962; Johnson and Tasker, 1974; FHWA, 1983; Potter, 1957a\&b; Talbot, 1887). 


\section{Description of the Water-Surface Profile Model (WSPRO) Analysis}

Datum for WSPRO analysis (USGS survey, sea level, VTAOT plans)

USGS survey

Datum tie between USGS survey and VTAOT plans

None

Description of reference marks used to determine USGS datum. $\quad$ RM1 is a chiseled X on top of the curb at the upstream left corner of the bridge (elev. $500.72 \mathrm{ft}$, arbitrary survey datum).

RM2 is a chiseled X on top of the curb at the downstream left corner of the bridge (elev. 500.76

$\mathrm{ft}$, arbitrary survey datum).

\section{Cross-Sections Used in WSPRO Analysis}

\begin{tabular}{|c|c|c|c|}
\hline${ }^{1}$ Cross-section & $\begin{array}{c}\text { Section } \\
\text { Reference } \\
\text { Distance } \\
\text { (SRD) in feet }\end{array}$ & $\begin{array}{c}{ }^{2} \text { Cross-section } \\
\text { development }\end{array}$ & Comments \\
\hline EXITX & -27 & 1 & Exit section \\
\hline FULLV & 0 & 2 & $\begin{array}{l}\text { Downstream Full-valley } \\
\text { section (Templated from } \\
\text { EXITX) }\end{array}$ \\
\hline BRIDG & 0 & 1 & Bridge section \\
\hline RDWAY & 14 & 1 & Road Grade section \\
\hline APPRO & 49 & 1 & Approach section \\
\hline
\end{tabular}

${ }^{1}$ For location of cross-sections see plan-view sketch included with Level I field form, Appendix E. For more detail on how cross-sections were developed see WSPRO input file. 


\section{Data and Assumptions Used in WSPRO Model}

Hydraulic analyses of the reach were done by use of the Federal Highway Administration's WSPRO step-backwater computer program (Shearman and others, 1986, and Shearman, 1990). The analyses reported herein reflect conditions existing at the site at the time of the study. Furthermore, in the development of the model it was necessary to assume no accumulation of debris or ice at the site. Results of the hydraulic model are presented in the Bridge Hydraulic Summary, Appendix B, and figure 7.

Channel roughness factors (Manning's " $n$ ") used in the hydraulic model were estimated using field inspections at each cross section following the general guidelines described by Arcement and Schneider (1989). Final adjustments to the values were made during the modelling of the reach. Channel " $n$ " values for the reach ranged from 0.050 to 0.055 , and overbank " $\mathrm{n}$ " values ranged from 0.050 to 0.070 .

Critical depth at the exit section (EXITX) was assumed as the starting water surface. Normal depth was computed by use of the slope-conveyance method outlined in the user's manual for WSPRO (Shearman, 1990), and resulted in a supercritical solution. Because normal depth was within $0.2 \mathrm{ft}$ of critical depth, the critical water surface was assumed to be a satisfactory starting water surface. The slope used was $0.0356 \mathrm{ft} / \mathrm{ft}$, which was estimated from the topographic map (U.S. Geological Survey, 1988).

The surveyed approach section (APPRO) was one bridge length upstream of the upstream face as recommended by Shearman and others (1986). This location provides a consistent method for determining scour variables. 


\section{Bridge Hydraulics Summary}

$\begin{array}{llll}\text { Average bridge embankment elevation } & 500.8 & f t \\ \text { Average low steel elevation } & 497.7 & \boldsymbol{f t}\end{array}$

100-year discharge $\quad 1,410 \quad \mathrm{ft}^{3} / \mathrm{s}$

Water-surface elevation in bridge opening $\quad 497.9 \quad f t$

Road overtopping? ___ No Discharge over road ___ - $\mathrm{ft}^{3} / \mathrm{s}$

Area of flow in bridge opening $\quad 154 \quad \mathrm{ft}^{2}$

Average velocity in bridge opening $\quad \begin{array}{lll}9.2 & \mathrm{ft} / \mathrm{s}\end{array}$

Maximum WSPRO tube velocity at bridge $\quad 11.5 \mathrm{ft} / \mathrm{s}$

Water-surface elevation at Approach section with bridge 499.9

Water-surface elevation at Approach section without bridge $\quad \overline{496.4}$

Amount of backwater caused by bridge $\quad 3.5$ it

500-year discharge $\quad 1,900 \quad \mathrm{ft}^{3} / \mathrm{s}$

Water-surface elevation in bridge opening $\quad 497.7$ ft

Road overtopping? ___ Yes Discharge over road __ $281, \beta^{3} / \mathrm{s}$

Area of flow in bridge opening $\quad 153 \quad \mathrm{ft}^{2}$

Average velocity in bridge opening $10.6 \mathrm{ft} / \mathrm{s}$

Maximum WSPRO tube velocity at bridge 15.0 's

Water-surface elevation at Approach section with bridge 501.2

Water-surface elevation at Approach section without bridge $\quad 497.4$

Amount of backwater caused by bridge $3.8, t$

Incipient overtopping discharge $\quad 1,480 \quad \mathrm{ft}^{3} / \mathrm{s}$

Water-surface elevation in bridge opening 497.9 it

\begin{tabular}{llcl} 
Area of flow in bridge opening & 154 & $\boldsymbol{f t}^{\mathbf{2}}$ & \\
\cline { 2 - 3 } Average velocity in bridge opening & $9.6 \quad \mathrm{ft} / \mathrm{s}$
\end{tabular}

Maximum WSPRO tube velocity at bridge $\quad 12.0 \mathrm{ft} / \mathrm{s}$

Water-surface elevation at Approach section with bridge

Water-surface elevation at Approach section without bridge

500.2

Amount of backwater caused by bridge $\quad 3.6$.t 


\section{Scour Analysis Summary}

\section{Special Conditions or Assumptions Made in Scour Analysis}

Scour depths were computed using the general guidelines described in Hydraulic Engineering Circular 18 (Richardson and others, 1995). Scour depths were calculated assuming an infinite depth of erosive material and a homogeneous particle-size distribution. The results of the scour analysis are presented in tables 1 and 2 and a graph of the scour depths is presented in figure 8 .

At this site, the 100-year, 500-year and incipient roadway-overtopping discharges resulted in unsubmerged orifice flow. Contraction scour at bridges with orifice flow is best estimated by use of the Chang pressure-flow scour equation (oral communication, J. Sterling Jones, October 4, 1996). Thus, contraction scour for these discharges was computed by use of the Chang equation (Richardson and others, 1995, p. 145-146). The computed streambed armoring depths suggest that armoring will not limit the depth of contraction scour.

For comparison, contraction scour for the discharges resulting in orifice flow was also computed by use of the Laursen clear-water contraction scour equation (Richardson and others, 1995, p. 32, equation 20) and the Umbrell pressure-flow equation (Richardson and others, 1995, p. 144) and presented in Appendix F. Furthermore, for those discharges resulting in unsubmerged orifice flow, contraction scour was computed by substituting estimates for the depth of flow at the downstream bridge face in the contraction scour equations. Results with respect to these substitutions are provided in Appendix F.

Abutment scour was computed by use of the Froehlich equation (Richardson and others, 1995, p. 48, equation 28). Variables for the Froehlich equation include the Froude number of the flow approaching the embankments, the length of the embankment blocking flow, and the depth of flow approaching the embankment less any roadway overtopping. 


\section{Scour Results}

\section{0-yr discharge 500-yr discharge}

Contraction scour:

(Scour depths in feet)

Main channel

Live-bed scour

Clear-water scour

Depth to armoring

Left overbank

Right overbank

Local scour:

Abutment scour

Left abutment

7.8

9.3

8.3

$7.6-$

$6.7-$

$7.7-$

Right abutment

Pier scour

Pier 1

Pier 2

Pier 3

\section{Abutments:}

Left abutment

Right abutment

Piers:

Pier 1

Pier 2

overtopping discharge 


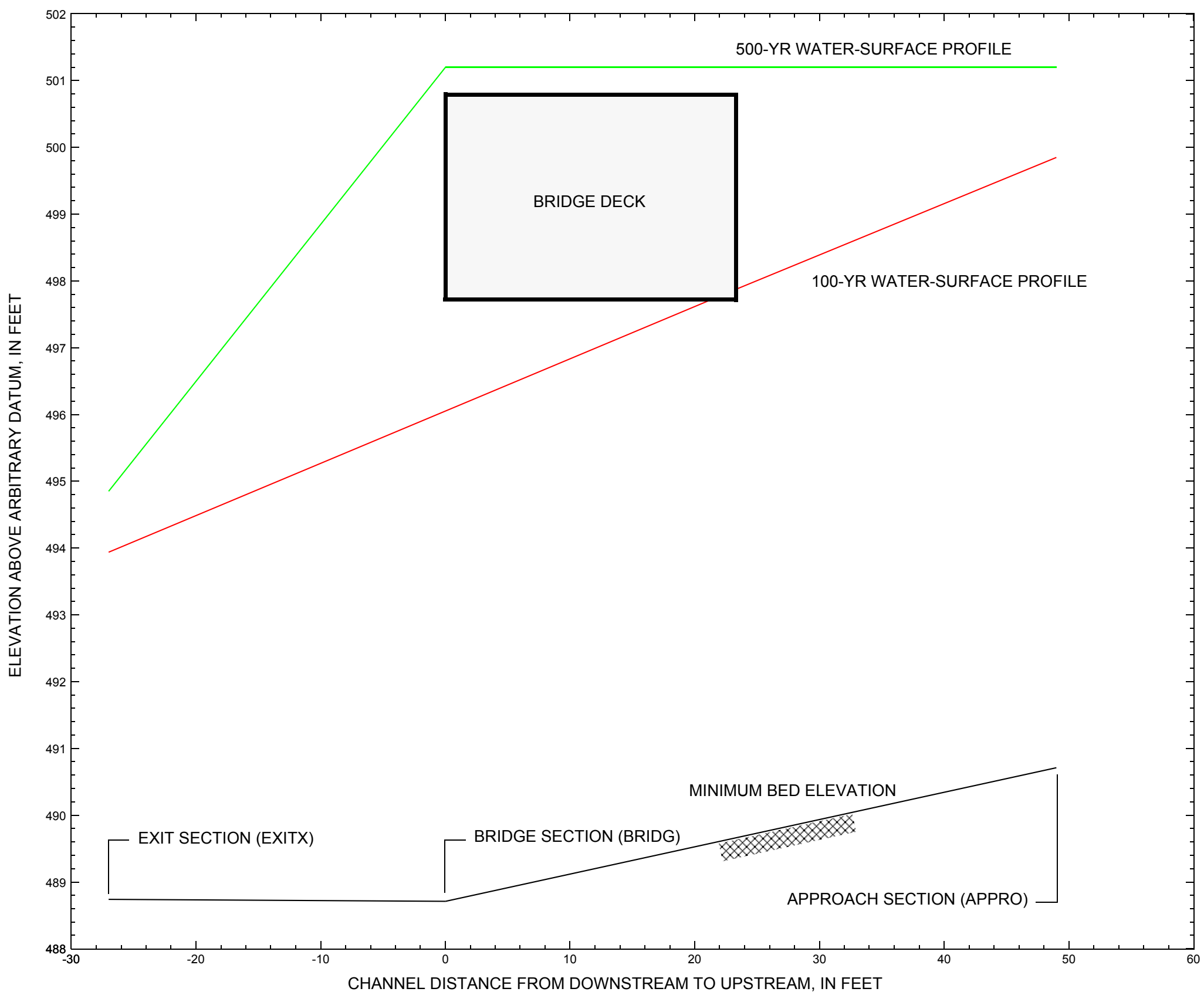

Figure 7. Water-surface profiles for the 100- and 500-yr discharges at structure BURKTH00070016 on Town Highway 7, crossing Dish Mill Brook, Burke, Vermont. 


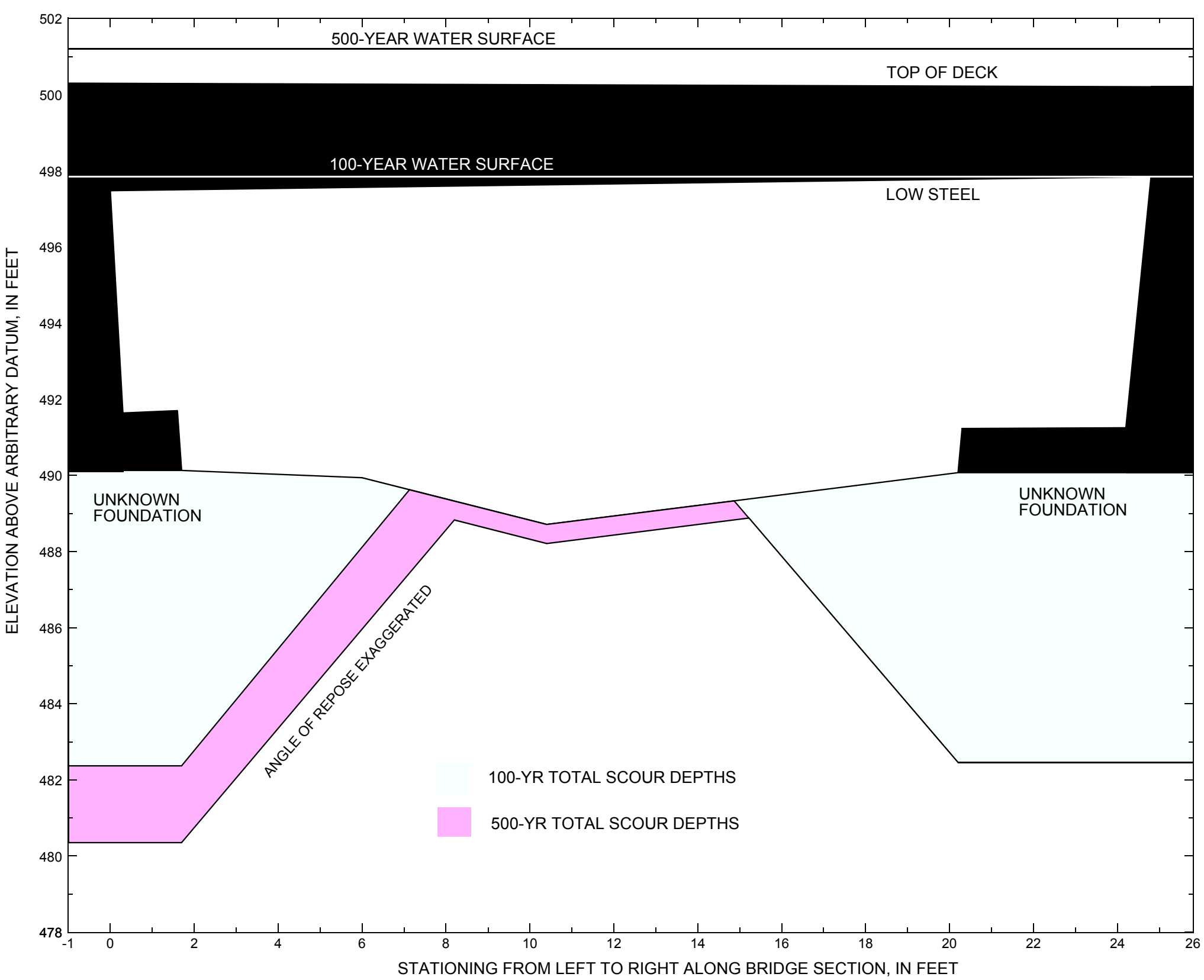

Figure 8. Scour elevations for the 100-yr and 500-yr discharges at structure BURKTH00070016 on Town Highway 7, crossing Dish Mill Brook, Burke, Vermont. 
Table 1. Remaining footing/pile depth at abutments for the 100-year discharge at structure BURKTH00070016 on Town Highway 7, crossing Dish Mill Brook, Burke, Vermont.

[VTAOT, Vermont Agency of Transportation; --,no data]

\begin{tabular}{|c|c|c|c|c|c|c|c|c|c|c|c|}
\hline Description & Station $^{1}$ & $\begin{array}{l}\text { VTAOT } \\
\text { minimum } \\
\text { low-chord } \\
\text { elevation } \\
\text { (feet) }\end{array}$ & $\begin{array}{c}\text { Surveyed } \\
\text { minimum } \\
\text { low-chord } \\
\text { elevation } \\
\text { (feet) }\end{array}$ & $\begin{array}{c}\text { Bottom of } \\
\text { footing/pile } \\
\text { elevation } \\
\text { (feet) }\end{array}$ & $\begin{array}{l}\text { Channel } \\
\text { elevation at } \\
\text { abutment/ } \\
\text { pier }^{2} \\
\text { (feet) }\end{array}$ & $\begin{array}{l}\text { Contraction } \\
\text { scour depth } \\
\text { (feet) }\end{array}$ & $\begin{array}{l}\text { Abutment } \\
\text { scour } \\
\text { depth } \\
\text { (feet) }\end{array}$ & $\begin{array}{l}\text { Pier } \\
\text { scour } \\
\text { depth } \\
\text { (feet) }\end{array}$ & $\begin{array}{l}\text { Depth of } \\
\text { total scour } \\
\text { (feet) }\end{array}$ & $\begin{array}{c}\text { Elevation of } \\
\text { scour }^{2} \\
\text { (feet) }\end{array}$ & $\begin{array}{c}\text { Remaining } \\
\text { footing/pile } \\
\text { depth } \\
\text { (feet) }\end{array}$ \\
\hline \multicolumn{12}{|c|}{100 -yr. discharge is 1,410 cubic-feet per second } \\
\hline Left abutment & 0.0 & -- & 497.5 & -- & 490.1 & 0.0 & 7.8 & -- & 7.8 & 482.3 & -- \\
\hline Right abutment & 24.8 & -- & 497.9 & -- & 490.1 & 0.0 & 7.6 & -- & 7.6 & 482.5 & -- \\
\hline
\end{tabular}

1.Measured along the face of the most constricting side of the bridge.

2.Arbitrary datum for this study.

Table 2. Remaining footing/pile depth at abutments for the 500-year discharge at structure BURKTH00070016 on Town Highway 7, crossing Dish Mill Brook, Burke, Vermont. [VTAOT, Vermont Agency of Transportation; --, no data]

\begin{tabular}{|c|c|c|c|c|c|c|c|c|c|c|c|}
\hline Description & Station $^{1}$ & $\begin{array}{l}\text { VTAOT } \\
\text { minimum } \\
\text { low-chord } \\
\text { elevation } \\
\text { (feet) }\end{array}$ & $\begin{array}{l}\text { Surveyed } \\
\text { minimum } \\
\text { low-chord } \\
\text { elevation } \\
\text { (feet) }\end{array}$ & $\begin{array}{c}\text { Bottom of } \\
\text { footing/pile } \\
\text { elevation }{ }^{2} \\
\text { (feet) }\end{array}$ & $\begin{array}{c}\text { Channel } \\
\text { elevation at } \\
\text { abutment/ } \\
\text { pier }^{2} \\
\text { (feet) }\end{array}$ & $\begin{array}{l}\text { Contraction } \\
\text { scour depth } \\
\text { (feet) }\end{array}$ & $\begin{array}{l}\text { Abutment } \\
\text { scour } \\
\text { depth } \\
\text { (feet) }\end{array}$ & $\begin{array}{l}\text { Pier } \\
\text { scour } \\
\text { depth } \\
\text { (feet) }\end{array}$ & $\begin{array}{l}\text { Depth of } \\
\text { total scour } \\
\text { (feet) }\end{array}$ & $\begin{array}{c}\text { Elevation of } \\
\text { scour }^{2} \\
\text { (feet) }\end{array}$ & $\begin{array}{c}\text { Remaining } \\
\text { footing/pile } \\
\text { depth } \\
\text { (feet) }\end{array}$ \\
\hline \multicolumn{12}{|c|}{500 -yr. discharge is 1,900 cubic-feet per second } \\
\hline Left abutment & 0.0 & -- & 497.5 & -- & 490.1 & 0.5 & 9.3 & -- & 9.8 & 480.3 & -- \\
\hline Right abutment & 24.8 & -- & 497.9 & -- & 490.1 & 0.5 & 6.7 & -- & 7.2 & 482.9 & -- \\
\hline
\end{tabular}

1.Measured along the face of the most constricting side of the bridge.

2.Arbitrary datum for this study. 


\section{SELECTED REFERENCES}

Arcement, G.J., Jr., and Schneider, V.R., 1989, Guide for selecting Manning's roughness coefficients for natural channels and flood plains:

U.S. Geological Survey Water-Supply Paper 2339, 38 p.

Barnes, H.H., Jr., 1967, Roughness characteristics of natural channels: U.S. Geological Survey Water-Supply Paper 1849,213 p.

Benson, M. A., 1962, Factors Influencing the Occurrence of Floods in a Humid Region of Diverse Terrain: U.S. Geological Survey WaterSupply Paper 1580-B, 64 p.

Brown, S.A. and Clyde, E.S., 1989, Design of riprap revetment: Federal Highway Administration Hydraulic Engineering Circular No. 11, Publication FHWA-IP-89-016, 156 p.

Federal Highway Administration, 1983, Runoff estimates for small watersheds and development of sound design: Federal Highway Administration Report FHWA-RD-77-158.

Federal Highway Administration, 1993, Stream Stability and Scour at Highway Bridges: Participant Workbook: Federal Highway Administration Report FHWA-HI-91-011.

Federal Emergency Management Agency, 1979, Flood Insurance Study, Town of Burke, Caledonia County, Vermont: Washington, D.C., December 1979.

Froehlich, D.C., 1989, Local scour at bridge abutments in Ports, M.A., ed., Hydraulic Engineering--Proceedings of the 1989 National Conference on Hydraulic Engineering: New York, American Society of Civil Engineers, p. 13-18.

Hayes, D.C.,1993, Site selection and collection of bridge-scour data in Delaware, Maryland, and Virginia: U.S. Geological Survey WaterResources Investigation Report 93-4017, 23 p.

Interagency Advisory Committee on Water Data, 1982, Guidelines for determining flood flow frequency: U.S. Geological Survey, Bulletin 17B of the Hydrology Subcommittee, 190 p.

Johnson, C.G. and Tasker, G.D.,1974, Progress report on flood magnitude and frequency of Vermont streams: U.S. Geological Survey OpenFile Report 74-130, 37 p.

Lagasse, P.F., Schall, J.D., Johnson, F., Richardson, E.V., Chang, F., 1995, Stream Stability at Highway Structures: Federal Highway Administration Hydraulic Engineering Circular No. 20, Publication FHWA-IP-90-014, 144 p.

Laursen, E.M., 1960, Scour at bridge crossings: Journal of the Hydraulics Division, American Society of Civil Engineers, v. 86, no. HY2, p. 39-53.

Potter, W. D., 1957a, Peak rates of runoff in the Adirondack, White Mountains, and Maine woods area, Bureau of Public Roads

Potter, W. D., 1957b, Peak rates of runoff in the New England Hill and Lowland area, Bureau of Public Roads

Richardson, E.V. and Davis, S.R., 1995, Evaluating scour at bridges: Federal Highway Administration Hydraulic Engineering Circular No. 18, Publication FHWA-IP-90-017, 204 p.

Richardson, E.V., Simons, D.B., and Julien, P.Y., 1990, Highways in the river environment: Federal Highway Administration Publication FHWA-HI-90-016.

Ritter, D.F., 1984, Process Geomorphology: W.C. Brown Co., Debuque, Iowa, 603 p.

Shearman, J.O., 1990, User's manual for WSPRO--a computer model for water surface profile computations: Federal Highway Administration Publication FHWA-IP-89-027, 187 p.

Shearman, J.O., Kirby, W.H., Schneider, V.R., and Flippo, H.N., 1986, Bridge waterways analysis model; research report: Federal Highway Administration Publication FHWA-RD-86-108, 112 p.

Talbot, A.N., 1887, The determination of water-way for bridges and culverts.

U.S. Department of Transportation, 1993, Stream stability and scour at highway bridges, Participant Workbook: Federal Highway Administration Publication FHWA HI-91-011.

U.S. Geological Survey, 1988, Burke Mountain, Vermont 7.5 Minute Series quadrangle map: U.S. Geological Survey Topographic Maps, Scale 1:24,000. 


\section{APPENDIX A: \\ WSPRO INPUT FILE}




\section{WSPRO INPUT FILE}

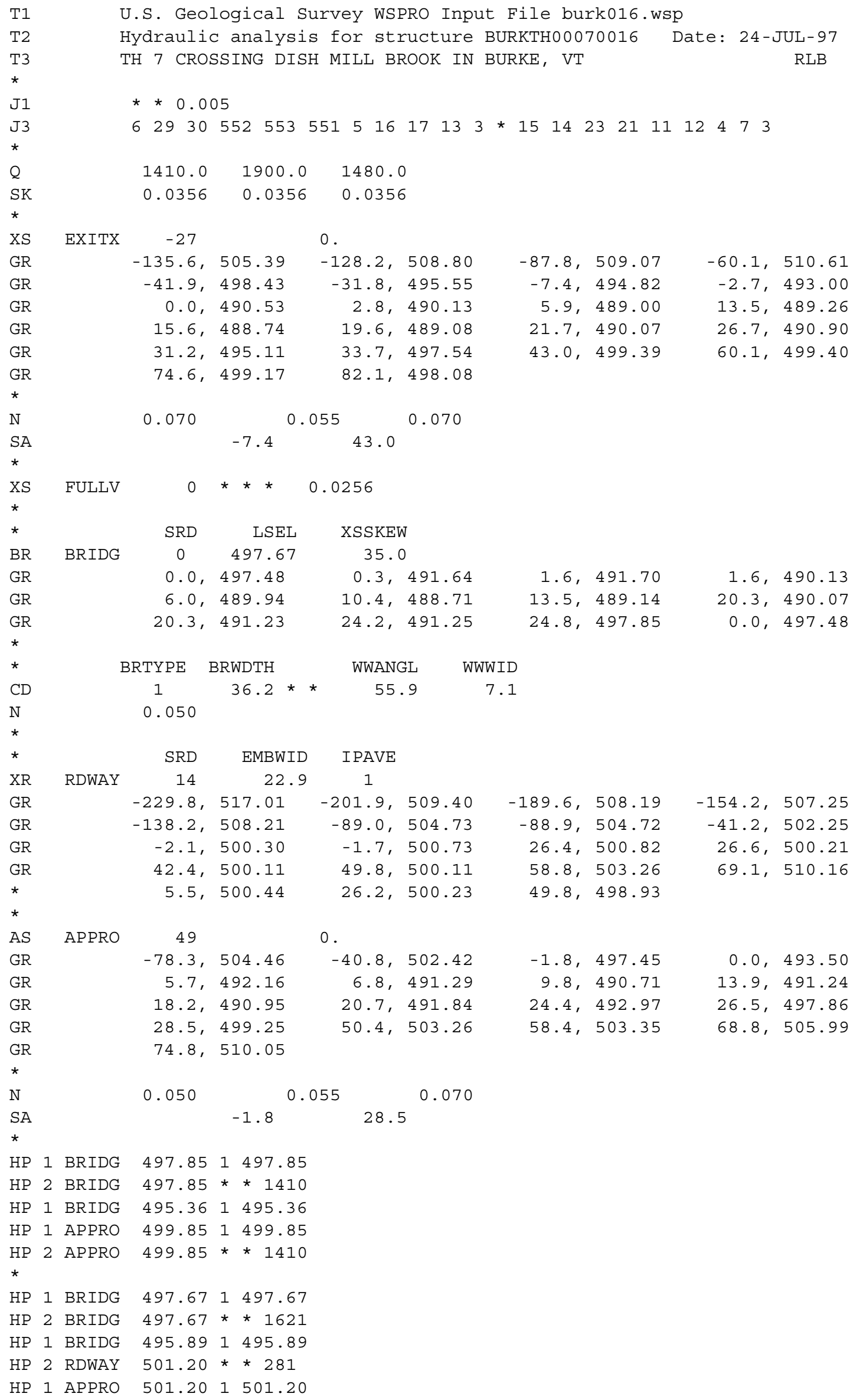




\section{APPENDIX B: \\ WSPRO OUTPUT FILE}


WSPRO OUTPUT FILE

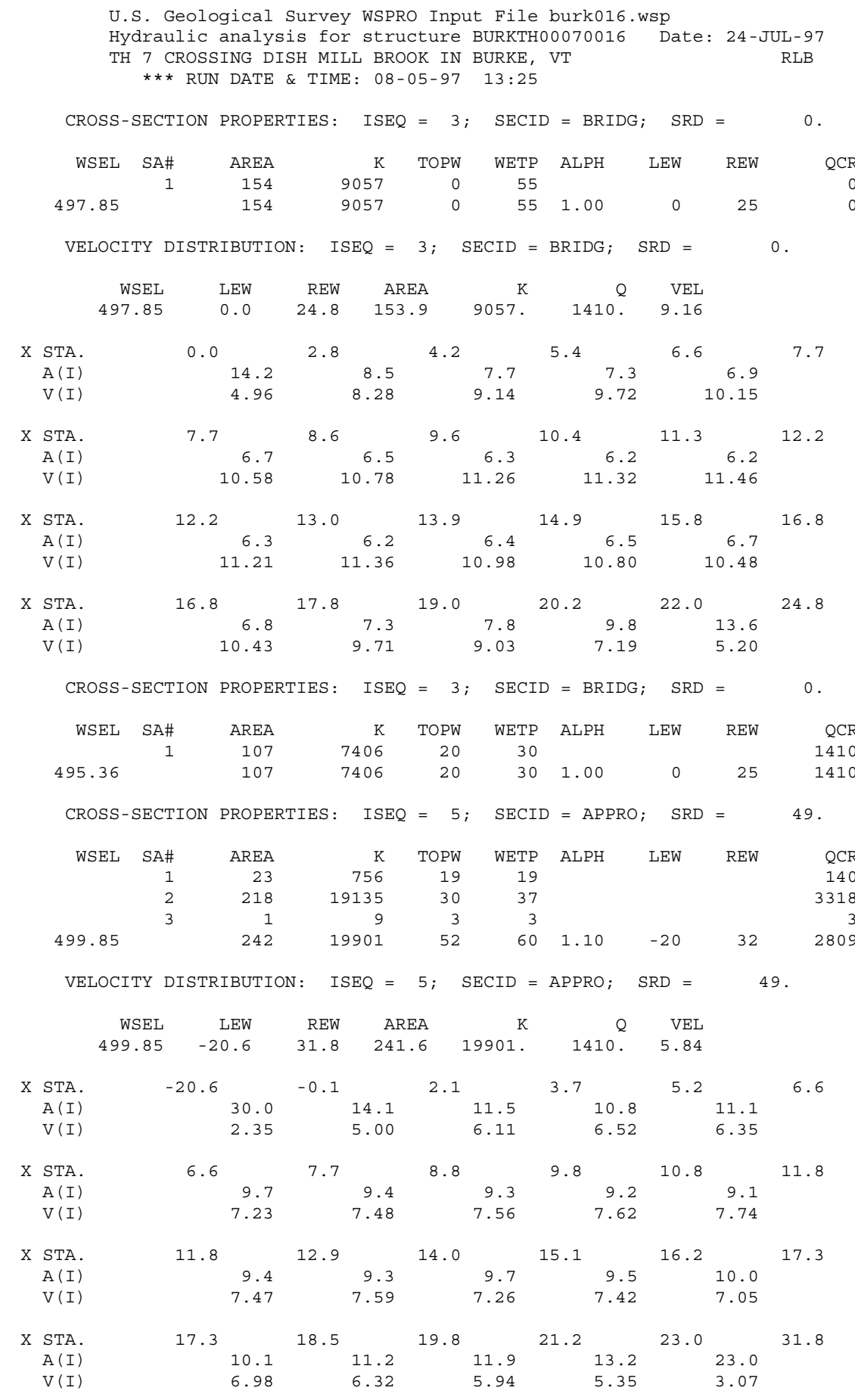


WSPRO OUTPUT FILE (continued)

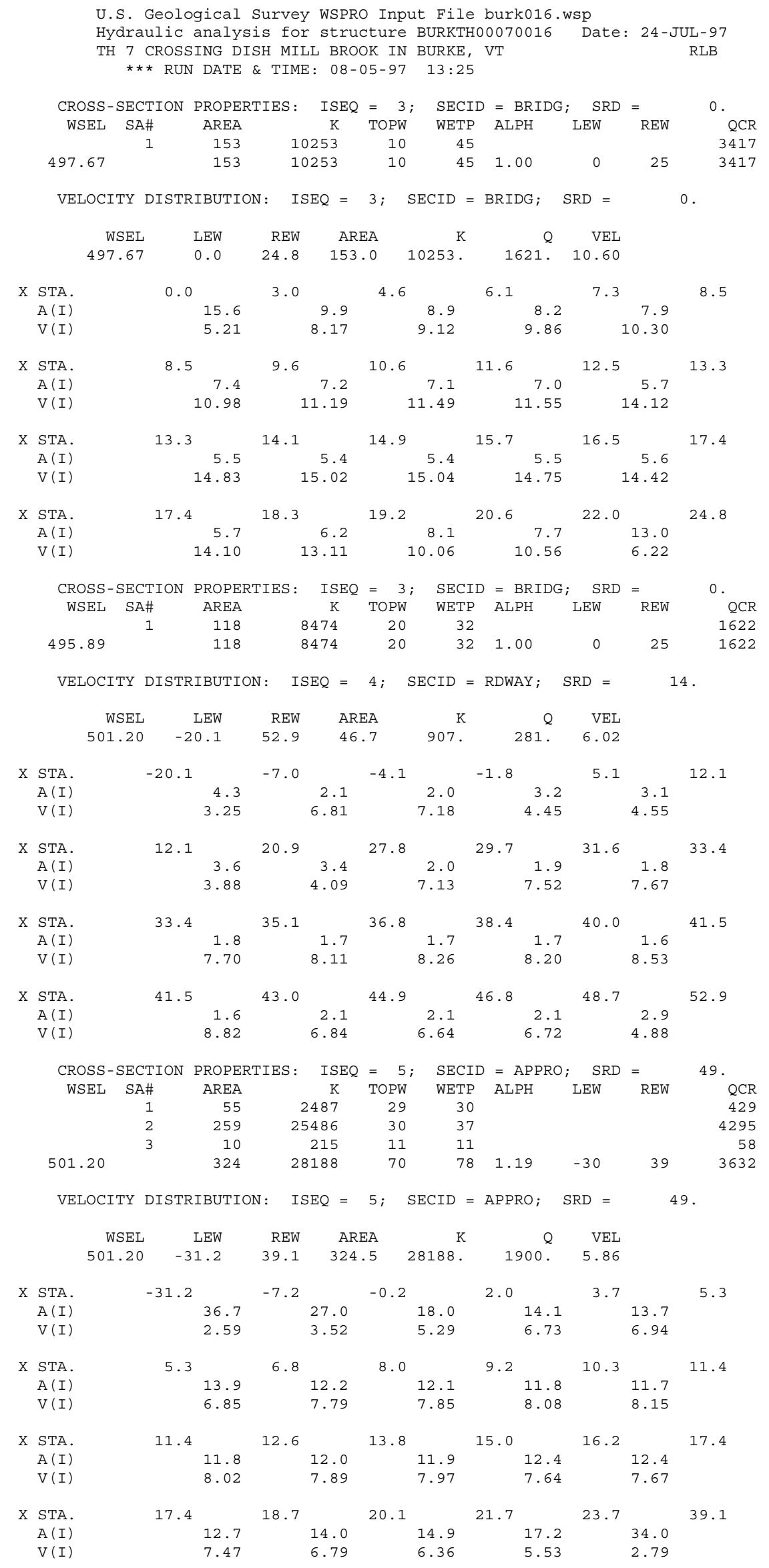


WSPRO OUTPUT FILE (continued)

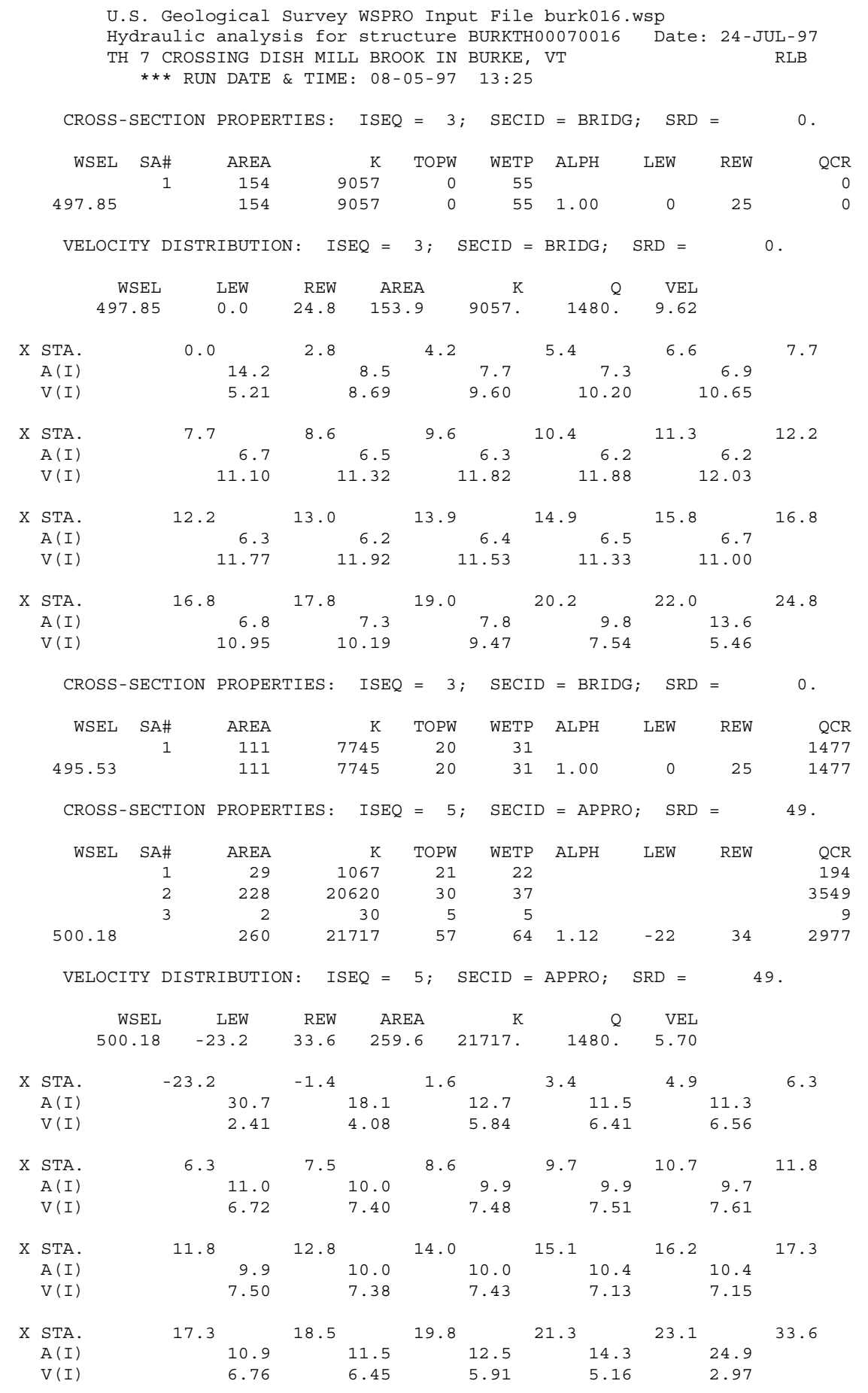


WSPRO OUTPUT FILE (continued)

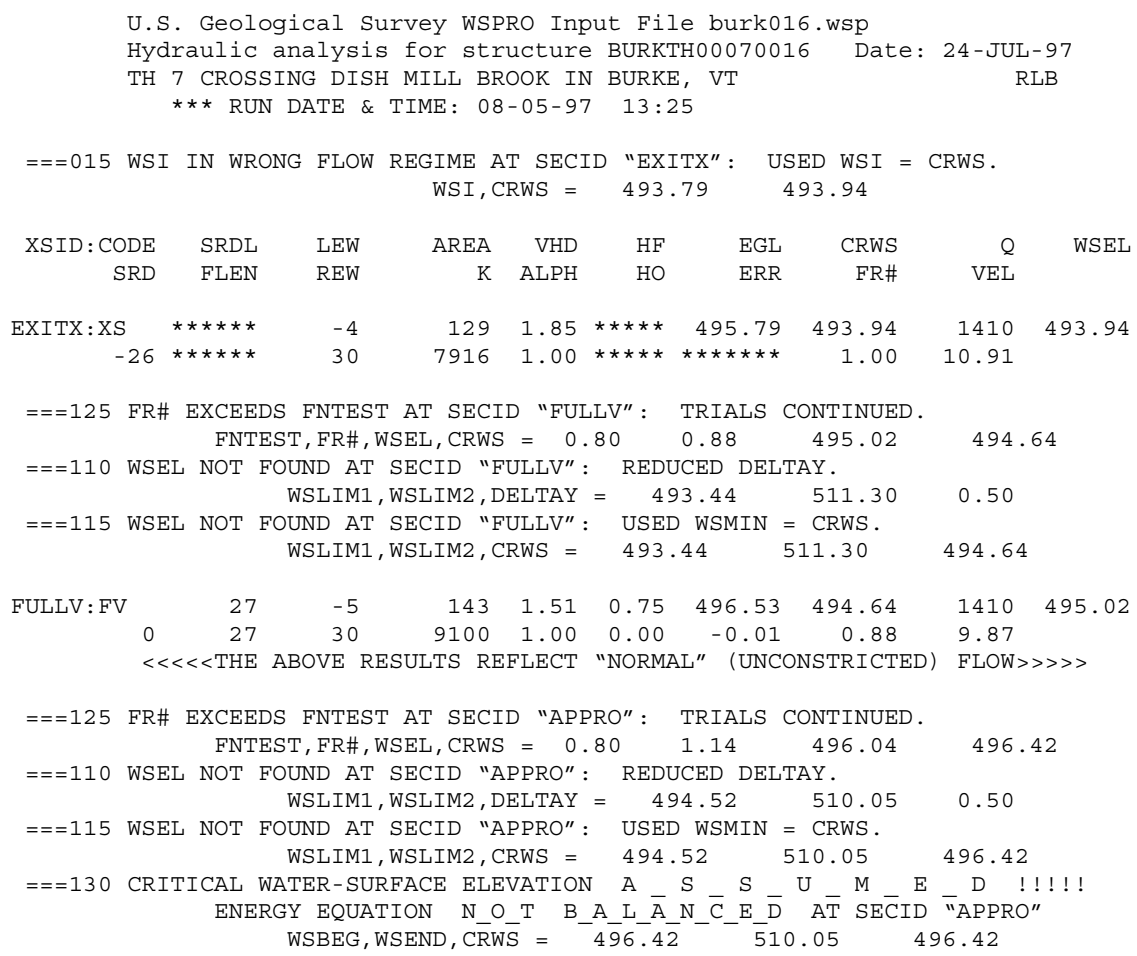


WSPRO OUTPUT FILE (continued)

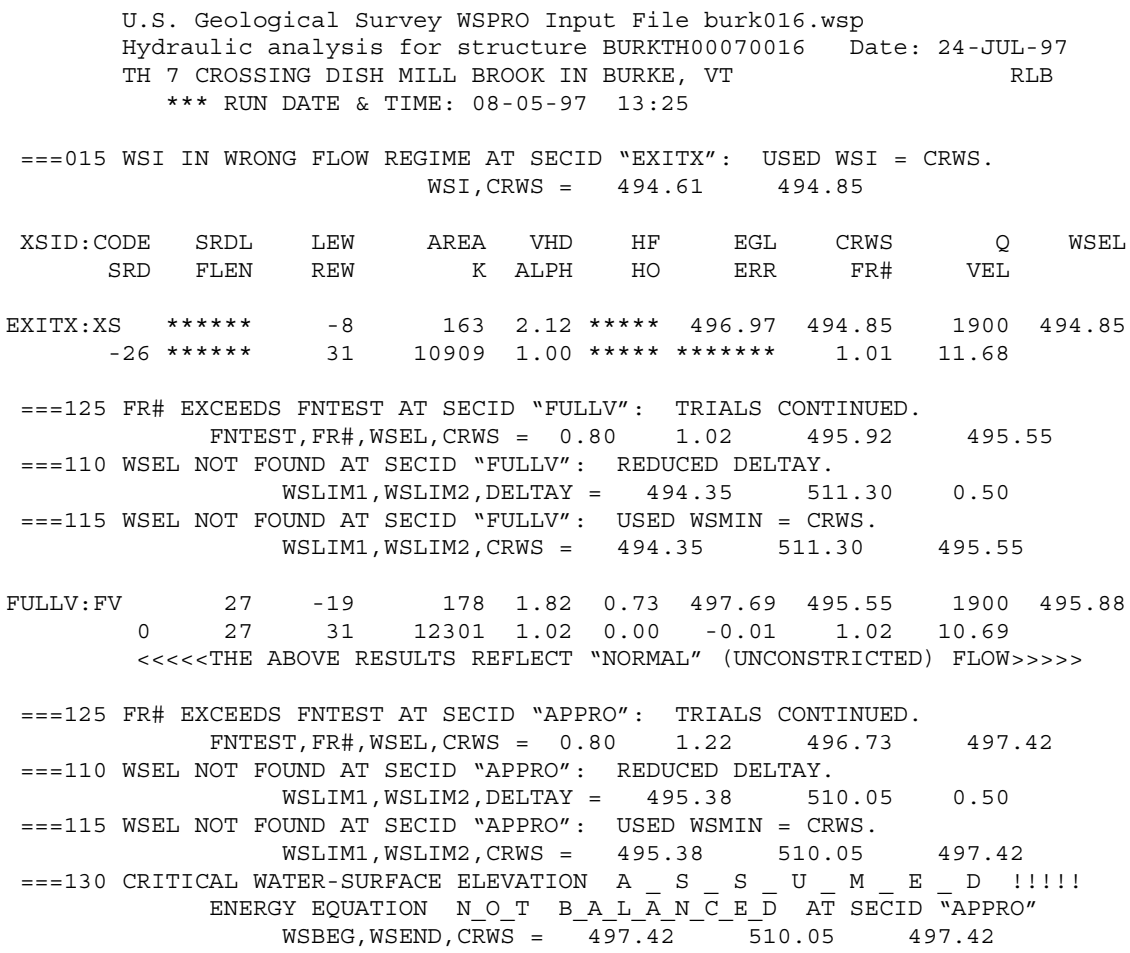


WSPRO OUTPUT FILE (continued)

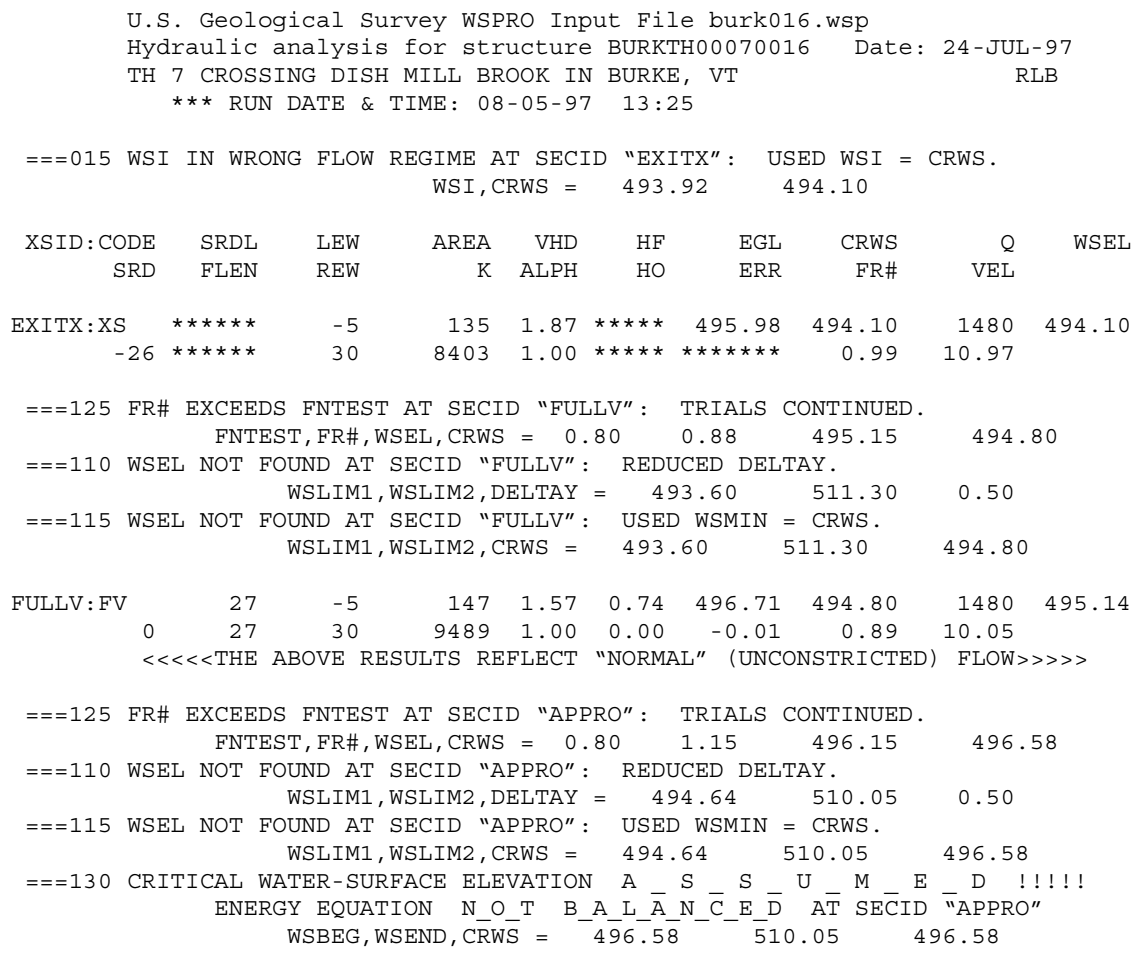




\section{APPENDIX C:}

\section{BED-MATERIAL PARTICLE-SIZE DISTRIBUTION}




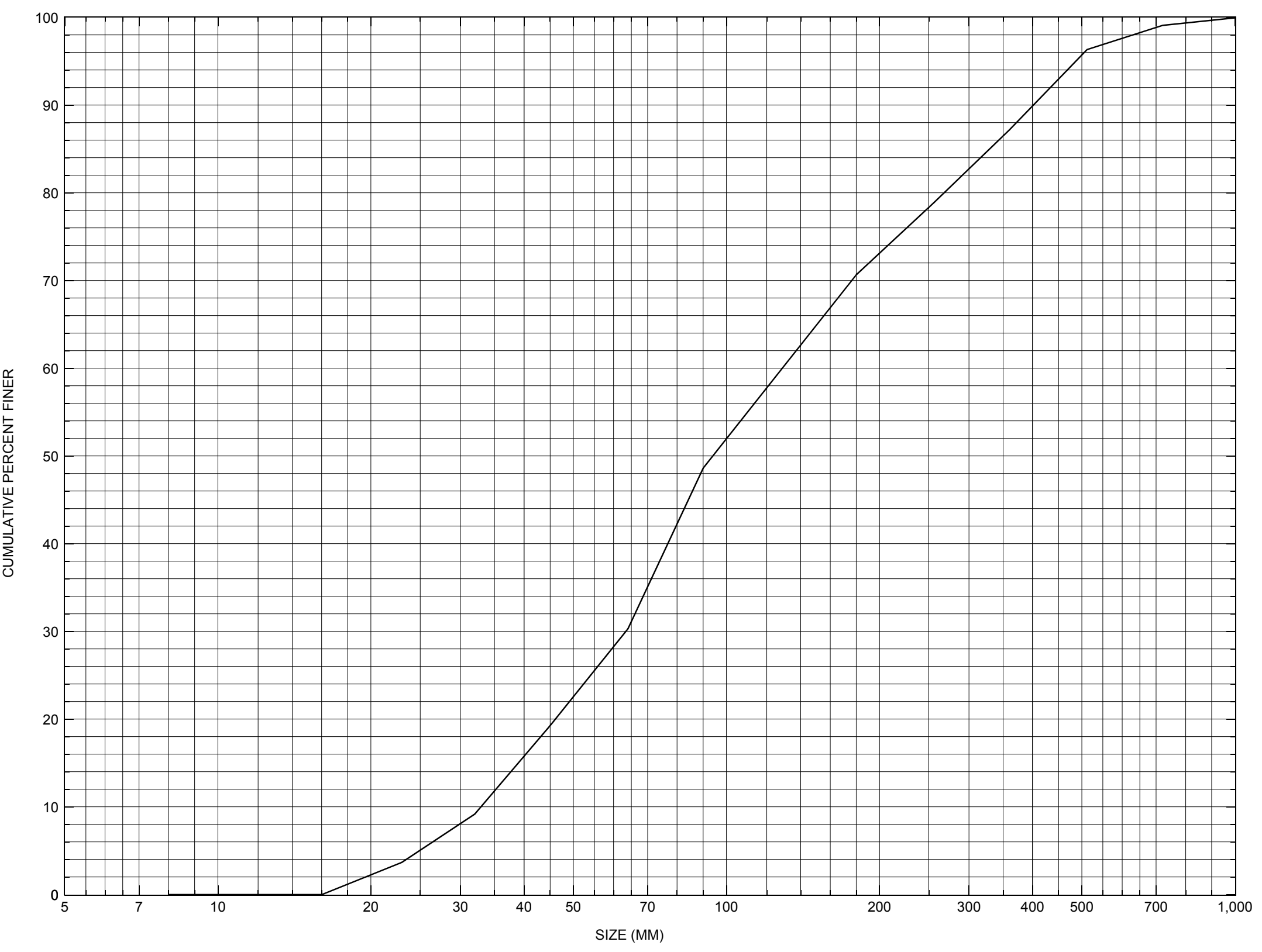

Appendix C. Bed material particle-size distribution for a pebble count in the channel approach of structure BURKTH00070016, in Burke, Vermont. 


\section{APPENDIX D: \\ HISTORICAL DATA FORM}




\section{Structure Number BURKTH00070016}

\section{General Location Descriptive}

Data collected by (First Initial, Full last name) $\mathbf{E}$. BOEHMLER

Date $(M M / D D / Y Y) \_\mathbf{0 3} / \underline{24} / \underline{95}$

Highway District Number (I - 2; nn) $\mathbf{0 7}$

Town (FIPS place code; I - 4; nnnnn) $\mathbf{1 0 4 5 0}$

Waterway ( $I$ - 6) DISH MILL BROOK

Route Number TH007

Topographic Map Burke Mountain

Latitude (I - 16; nnnn.n) $\mathbf{4 4 3 5 4}$
County (FIPS county code; I - 3; nnn)

Mile marker (I - 11; nnn.nnn) $\mathbf{0 0 0 0 0 0}$

Road Name (I - 7): -

Vicinity (I - 9) 0.5 MI JCT TH 7 + VT 114

Hydrologic Unit Code: $\mathbf{0 1 0 8 0 1 0 2}$

Longitude (i - 17; nnnnn.n) 71559

\section{Select Federal Inventory Codes}

FHWA Structure Number (I - 8) $\mathbf{1 0 0 3 0 2 0 0 1 6 0 3 0 2}$

Maintenance responsibility $(I-21 ; n n) \quad \mathbf{0 3}$

Year built (I - 27; YYYY) 1929

Average daily traffic, ADT (I - 29; nnnnnn) 000800

Year of ADT (I - 30; YY) $\mathbf{9 2}$

Opening skew to Roadway $(I-34 ; n n) \quad 34$

Operational status $(I-41 ; X) \quad \mathbf{A}$

Structure type (I - 43; nnn) $\mathbf{3 0 2}$

Approach span structure type $(I-44 ; n n n) \quad \mathbf{0 0 0}$

Number of spans (I - 45; nnn) $\mathbf{0 0 1}$

Number of approach spans (I - 46; nnnn) $\mathbf{0 0 0 0}$

Comments:

The structural inspection report of 10/31/94 indicates the structure is a steel stringer type bridge with a concrete deck and an asphalt roadway surface. The abutment walls and wingwalls are concrete, which have a few fine cracks, leaks, and areas of surface spalling noted overall. In addition, a random vertical crack and leak is reported on the left abutment wall. Similarly, a settlement crack is noted in the right abutment wall which extends down through the footing. The report gives the impression that both concrete footings are exposed. The right abutment is reported undermined in a 8 foot section centered on the centerline of the roadway by up to 30 inches horizontally. (Continued, page 33) 


\section{Bridge Hydrologic Data}

Is there hydrologic data available? $\underline{\mathbf{Y}}$ if No, type ctrl-n $h \quad$ VTAOT Drainage area $\left(\mathrm{mi}^{2}\right): \underline{\mathbf{6 . 0}}$

Terrain character:

Stream character \& type: -

Streambed material: Small stones and boulders

Discharge Data (cfs): $\quad \mathrm{Q}_{2.33} \frac{-}{\mathbf{1 4 0 0}}$

$$
\mathrm{Q}_{50} \mathbf{1 4 0 0}
$$

$\mathrm{Q}_{10} \frac{\mathbf{8 0 0}}{\mathrm{Q}_{100} \mathbf{1 7 0 0}}$

$\mathrm{Q}_{25} \frac{\mathbf{1 1 0 0}}{\mathrm{Q}_{500}-}$

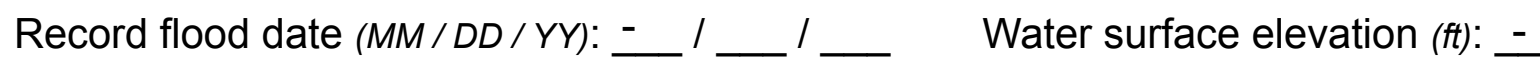

Estimated Discharge (cfs): _- Velocity at Q $\underline{\mathbf{5 0}}$ (ft/s): $\underline{\mathbf{1 4 . 7}}$

Ice conditions (Heavy, Moderate, Light) : -

Debris (Heavy, Moderate, Light):

The stage increases to maximum highwater elevation (Rapidly, Not rapidly): -

The stream response is (Flashy, Not flashy):

Describe any significant site conditions upstream or downstream that may influence the stream's

stage: There is a current proposal to straighten the channel and riprap the channel edges in some

locations in an effort to eliminate 2 other bridges over the same waterway further upstream.

The VTAOT is currently procuring the Corp. of engineers for a permit to do this work.

Watershed storage area (in percent): - $\%$

The watershed storage area is: - (1-mainly at the headwaters; 2- uniformly distributed; 3-immediatly upstream oi the site)

Water Surface Elevation Estimates for Existing Structure:

\begin{tabular}{|l|l|l|l|l|l|}
\hline Peak discharge frequency & $Q_{2.33}$ & $Q_{10}$ & $Q_{25}$ & $Q_{50}$ & $Q_{100}$ \\
Water surface elevation (ft)) & - & $\mathbf{2 . 7}$ & $\mathbf{3 . 2}$ & $\mathbf{3 . 6}$ & $\mathbf{4 . 1}$ \\
Velocity $(\mathrm{ft} / \mathrm{sec})$ & - & - & - & $\mathbf{1 4 . 7}$ & - \\
\hline
\end{tabular}

Long term stream bed changes: -

Is the roadway overtopped below the $\mathrm{Q}_{100}$ ? (Yes, No, Unknown): $\mathbf{U} \quad$ Frequency: -

Relief Elevation $(f t)$ :

Discharge over roadway at $Q_{100}\left(f^{3} / \mathrm{sec}\right)$ : _

Are there other structures nearby? (Yes, No, Unknown): $\mathbf{Y}$ Upstream distance (miles): $\mathbf{0 . 3}$ Town: Burke If No or Unknown, type ctrl-n os

Highway No. : $\mathbf{T H 0 7}$ Structure No. : 17 Year Built: 1929 Clear span $(f t): \underline{\mathbf{2 3 . 2}}$ Clear Height $(f t): \underline{\mathbf{7 . 0}}$ Full Waterway $\left(f^{2}\right): \underline{\mathbf{1 6 2 . 4}}$ 
Downstream distance (miles): $\underline{0.5}$ Town:

Highway No. : Structure No. : 13

Clear span (ft): 29.0 Clear Height $(f t): \underline{\mathbf{1 1 . 0}}$ Structure Type: Concrete, Steel beam

Comments:

A few boulders are present at the ends of each wingwall and along the banks upstream and downstream of the bridge. Bank erosion upstream and downstream is evident from previous flooding.

\section{USGS Watershed Data}

Watershed Hydrographic Data

Drainage area $(D A)$

Watershed storage (ST) 6.03

Bridge site elevation 964

Main channel length 4.33 $10 \%$ channel length elevation $\quad \mathbf{1 0 6 0}$

Main channel slope

(S) 258.65 $\mathrm{ft} / \mathrm{mi}$ $\%$ mi

Lake/pond/swamp area $\mathbf{0}$ $\mathrm{mi}^{2}$ Headwater elevation $\lcm{2474 \quad \mathrm{ft}}$ $\mathrm{ft} \quad 85 \%$ channel length elevation 1900 $\mathrm{ft}$

Watershed Precipitation Data

Average site precipitation in Average headwater precipitation in

Maximum 2yr-24hr precipitation event $(124,2)$ in

Average seasonal snowfall (Sn) $\mathrm{ft}$ 


\section{Bridge Plan Data}

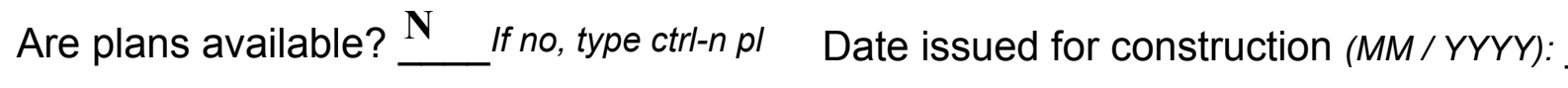

Project Number

Minimum channel bed elevation:

Low superstructure elevation: USLAB DSLAB USRAB DSRAB Benchmark location description:

NO BENCHMARK INFORMATION

Reference Point (MSL, Arbitrary, Other): Datum (NAD27, NAD83, Other):

Foundation Type: 4

If 1 : Footing Thickness

If 2: Pile Type:

If 3: Footing bottom elevation:

Is boring information available? $\mathbf{N}$

Foundation Material Type: $\mathbf{3}$

(1-Spreadfooting; 2-Pile; 3- Gravity; 4-Unknown)

Footing bottom elevation: -

Briefly describe material at foundation bottom elevation or around piles:

NO FOUNDATION MATERIAL INFORMATION

Comments:

NO PLANS. 


\section{Cross-sectional Data}

Is cross-sectional data available? $\underline{\mathbf{Y}}$

If no, type ctrl-n xs

Source (FEMA, VTAOT, Other)? VTAOT

Comments: This cross section is the downstream face. The low chord elevations are from the survey log done for this report on $8 / 7 / 95$. The low chord to bed length data is from the sketch attached to a bridge inspection report dated 10/31/94. The sketch was done on 10/27/92.

\begin{tabular}{|l|l|l|l|l|l|l|l|l|l|l|l|}
\hline Station & $\mathbf{0}$ & $\mathbf{3}$ & $\mathbf{6 . 3}$ & $\mathbf{1 2 . 5}$ & $\mathbf{1 5 . 8}$ & $\mathbf{1 7 . 6}$ & $\mathbf{1 9 . 2}$ & - & - & - & - \\
\hline Feature & RAB & - & - & - & - & - & LAB & - & - & - & - \\
\hline $\begin{array}{l}\text { Low chord } \\
\text { elevation }\end{array}$ & 497.9 & 497.8 & 497.8 & 497.7 & 497.6 & 497.5 & 497.5 & - & - & - & - \\
\hline $\begin{array}{l}\text { Bed } \\
\text { elevation }\end{array}$ & 491.5 & 489.5 & 488.8 & 489.1 & 489.9 & 489.9 & 491.3 & - & - & - & - \\
\hline $\begin{array}{l}\text { Low chord- } \\
\text { bed }\end{array}$ & 6.4 & $\mathbf{8 . 3}$ & $\mathbf{9 . 0}$ & $\mathbf{8 . 6}$ & 7.8 & 7.6 & 6.2 & - & - & - & - \\
\hline Station & - & - & - & - & - & - & - & - & - & - & - \\
\hline Feature & - & - & - & - & - & - & - & - & - & - & - \\
\hline $\begin{array}{l}\text { Low chord } \\
\text { elevation }\end{array}$ & - & - & - & - & - & - & - & - & - & - & - \\
\hline $\begin{array}{l}\text { Bed } \\
\text { elevation }\end{array}$ & - & - & - & - & - & - & - & - & - & - & - \\
\hline $\begin{array}{l}\text { Low chord- } \\
\text { bed }\end{array}$ & - & - & - & - & - & - & - & - & - & - & - \\
\hline
\end{tabular}

Source (FEMA, VTAOT, Other)?

Comments:

\begin{tabular}{|l|l|l|l|l|l|l|l|l|l|l|l|}
\hline Station & - & - & - & - & - & - & - & - & - & - & - \\
\hline Feature & - & - & - & - & - & - & - & - & - & - & - \\
\hline $\begin{array}{l}\text { Low chord } \\
\text { elevation }\end{array}$ & - & - & - & - & - & - & - & - & - & - & - \\
\hline $\begin{array}{l}\text { Bed } \\
\text { elevation }\end{array}$ & - & - & - & - & - & - & - & - & - & - & - \\
\hline $\begin{array}{l}\text { Low chord- } \\
\text { bed }\end{array}$ & - & - & - & - & - & - & - & - & - & - & - \\
\hline Station & - & - & - & - & - & - & - & - & - & - & - \\
\hline Feature & - & - & - & - & - & - & - & - & - & - & - \\
\hline $\begin{array}{l}\text { Low chord } \\
\text { elevation }\end{array}$ & - & - & - & - & - & - & - & - & - & - & - \\
\hline $\begin{array}{l}\text { Bed } \\
\text { elevation }\end{array}$ & - & - & - & - & - & - & - & - & - & - & - \\
\hline $\begin{array}{l}\text { Low chord- } \\
\text { bed }\end{array}$ & - & - & - & - & - & - & - & - & - & - & - \\
\hline
\end{tabular}




\section{APPENDIX E: \\ LEVEL I DATA FORM}


U. S. Geological Survey

Bridge Field Data Collection and Processing Form

Qa/Qc Check by: $\mathbf{R B}$ Date: $2 / 28 / 96$

\section{Structure Number}

BURKTH00070016

Computerized by: $\underline{\mathbf{R B}}$ Date: $2 / 28 / 96$

Reviewd by: $\quad$ RB Date: $\underline{\mathbf{8} / \mathbf{8} / 97}$

\section{A. General Location Descriptive}

1. Data collected by (First Initial, Full last name) $\mathbf{T}$. SEVERANCE

Date $(M M / D D / Y Y)$

08

$07 / 1995$

2. Highway District Number 07

County CALEDONIA 005

Waterway (I - 6) DISH MILL BROOK

Route Number $\mathbf{\text { TH07 }}$

Mile marker 0000

Town BURKE 10450

Road Name -

Hydrologic Unit Code: $\mathbf{0 1 0 8 0 1 0 2}$

3. Descriptive comments:

Located about 0.5 miles east of the intersection of TH07 with VT114.

\section{B. Bridge Deck Observations}
4. Surface cover... LBUS 5
RBUS 6
LBDS 6
RBDS 6
Overall 6

(2b us,ds,lb,rb: 1- Urban; 2- Suburban; 3- Row crops; 4- Pasture; 5- Shrub- and brushland; 6- Forest; 7- Wetland)
5. Ambient water surface... US 2
UB 1
DS 1
(1- pool; 2- riffle)

6. Bridge structure type 1 (1- single span; 2- multiple span; 3- single arch; 4- multiple arch; 5-cylindrical culvert; 6- box culvert; or 7- other)
7. Bridge length $\underline{28}$
(feet)
Span length $\mathbf{2 4}$
(feet)
Bridge width 22.9 (feet)

\section{Road approach to bridge:}
8. LB 2 RB 1
( 0 even, 1- lower, 2- higher)
9. LB 1
RB 1
(1-Paved, 2- Not paved)

10. Embankment slope (run / rise in feet / foot)

US left

US right

\begin{tabular}{|c|c|c|c|}
\hline \multicolumn{2}{|c|}{ Protection } & \multirow{2}{*}{ 13.Erosion } & 14.Severity \\
\hline 11.Type & 12.Cond. & $\mathbf{3}$ & $\mathbf{1}$ \\
\hline $\mathbf{0}$ & - & $\underline{\mathbf{3}}$ & $\mathbf{1}$ \\
\hline $\mathbf{0}$ & - & $\underline{\mathbf{2}}$ & $\mathbf{1}$ \\
\hline $\mathbf{0}$ & - & $\mathbf{3}$ & $\mathbf{1}$ \\
$\mathbf{0}$ & - & $\mathbf{3}$ & $\mathbf{1}$ \\
\hline
\end{tabular}

Bank protection types: 0- none; 1- < 12 inches,

2- $<36$ inches; $3-<48$ inches;

4- < 60 inches; 5- wall / artificial levee

Bank protection conditions: 1- good; 2- slumped;

3- eroded; 4- failed

Erosion: 0 - none; 1- channel erosion; 2 -

road wash; 3- both; 4- other

Erosion Severity: 0 - none; 1- slight; 2- moderate; 3- severe

\section{Channel approach to bridge (BF):}

15. Angle of approach: 15

16. Bridge skew: $\mathbf{3 5}$

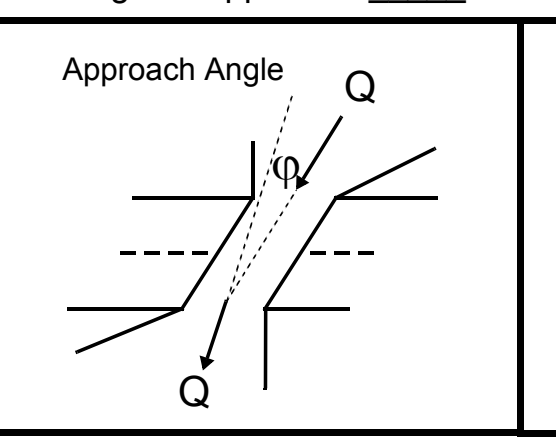

17. Channel impact zone 1 :

Where? RB (LB, RB)

Range? 3 feet US

Channel impact zone 2:

Where? RB (LB, RB) Bridge Skew Angle

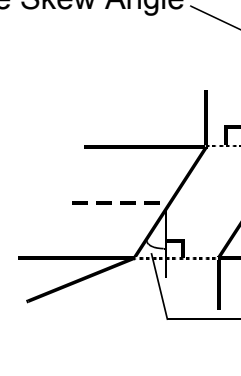

\section{Exist? $\mathbf{Y}(Y$ or $N)$}

Severity 1

$U B, D S$

$D S)$ to $\mathbf{0}$ feet DS

Opening skew to roadway

$\alpha=35.0$ 
18. Bridge Type: 1a

1a- Vertical abutments with wingwalls

$1 \mathrm{~b}$ - Vertical abutments without wingwalls

2- Vertical abutments and wingwalls, sloping embankment Wingwalls parallel to abut. face

3- Spill through abutments

4- Sloping embankment, vertical wingwalls and abutments

Wingwall angle less than $90^{\circ}$.

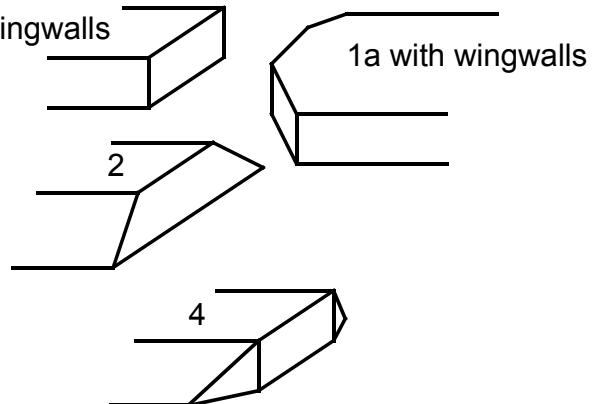

19. Bridge Deck Comments (surface cover variations, measured bridge and span lengths, bridge type variations, approach overflow width, etc.)

Three vertical concrete posts are along both bridge faces, each with two steel braided cables. The cable extends 15 feet up hill on the US left bank and 5 feet beyond bridge on the US right bank. The left bank DS cables extend up hill but the anchors to the ground are damaged (pulled out of the wood post) and the right bank DS cables have been ripped out of the post. The left bank US concrete post reads "1928."

7. Values are from VT AOT files. Measured bridge length $=\mathbf{2 9 . 2}$ feet, span length $=\mathbf{2 4 . 3}$ feet, and bridge width $=22.2$ feet. Paved roadway width perpendicular to the road is 19.7 feet.

4. Immediate banks are densely vegetated with shrubs and brush.

13. Some channel erosion is evident. Abundant rock fill has been placed along the channel edge on the left bank US from the wingwall to $75 \mathrm{ft}$ US.

\section{Upstream Channel Assessment}

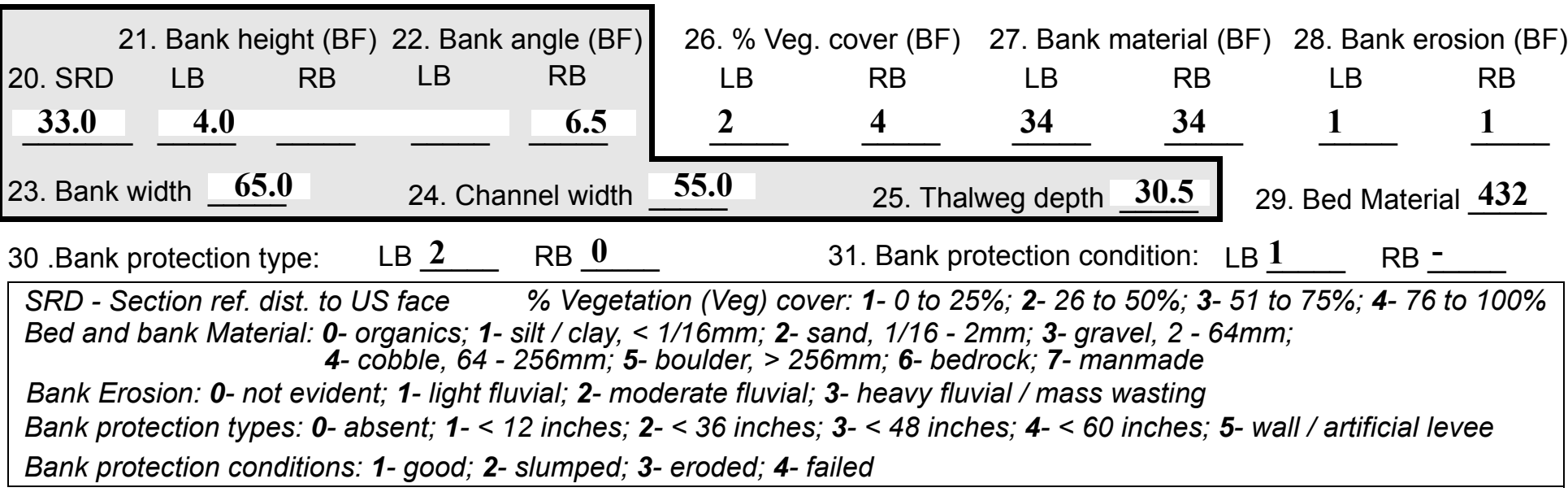

32. Comments (bank material variation, minor inflows, protection extent, etc.):

27. Bank material is composed of small to large cobbles and a few small boulders.

30. Boulders have been used as back fill for both US wingwalls but only extends US on the left bank. Bank protection extends from 0 feet US to 40 feet US on the left bank. 

feet $\underline{\text { US }}$

(US, UB, DS) positioned $\mathbf{0}$ \%LB to $\mathbf{5 0}$ $\% \mathrm{RB}$

37. Material: 4

38. Point or side bar comments (Circle Point or Side; Note additional bars, material variation, status, etc.):

This side bar is beyond 2 bridge lengths.

39. Is a cut-bank present? $\underline{\mathbf{Y}}$ ( $Y$ or if $N$ type ctrl-n $c b)$

41. Mid-bank distance: $\mathbf{4 0}$

42. Cut bank extent: $\mathbf{0}$

40. Where? $\underline{\mathbf{R B}}$ (LB or $R B)$

43. Bank damage: 1

(1- eroded and/or creep; 2- slip failure; 3- block failure)

44. Cut bank comments (eg. additional cut banks, protection condition, etc.):

The fines have been washed from much of this section leaving cobbles and boulders exposed. Some have fallen into the river bed and lie at the edgeof the channel. Some slumping of the bank at the US left wingwall has occurred. Debris from high flow has accumulated here. Another cut bank exists from 40 feet US to 90 feet US on the left bank.

\section{Is channel scour present? $\mathbf{Y}$ (Y or if $N$ type ctrl-n cs) 46. Mid-scour distance: 1 UB}

47. Scour dimensions: Length $\mathbf{3}$ Width 3

Depth : 1.75

Position 45

$\%$ LB to $\underline{55}$

$\%$ RB

48. Scour comments (eg. additional scour areas, local scouring process, etc.):

Mid scour distance is 1 foot DS from the US bridge face in the middle of the channel. There are four adjacent pooled areas starting at the US bridge face. The first is the channel scour described above. Just after this pool is a large rock in the center of the channel, $1 / 3$ of the channel width. Consequently, most of the flow is forced quickly left and right along the footing walls to the DS bridge

face. Another small scour hole is at the DS bridge face from 50\% LB to $60 \%$ RB; 6 feet long, 4 feet wide, and 1 foot deep.

\section{Are there major confluences? $\mathbf{N}$}

51. Confluence 1: Distance Confluence 2: Distance 52. Enters on Enters on 54. Confluence comments (eg. confluence name):

NO MAJOR CONFLUENCES
50. How many? -
53. Type- ( 1- perennial; 2- ephemeral) Type - (1-perennial; 2-ephemeral) ( $(L B$ or $R B)$ (LB or $R B)$ (1-perennial; 2-ephemeral) 
65. Debris and Ice Is there debris accumulation?

67. Debris Potential 1 (1- Low; 2- Moderate; 3- High)

69. Is there evidence of ice build-up? 2

70. Debris and Ice Comments:

2

Various examples of debris, grass, branches, and small logs, have accumulated on the banks.
$(Y$ or $N)$ 66. Where? $\mathbf{Y}$ (1- Upstream; 2- At bridge; 3- Both) 68. Capture Efficiency 2 (1- Low; 2- Moderate; 3- High) Ice Blockage Potential $\underline{\mathbf{Y}}$ (1- Low; 2- Moderate; 3- High)

\begin{tabular}{|l|c|c|c|c|c|c|c|c|}
\hline Abutments & $\begin{array}{c}71 . \text { Attack } \\
\angle \text { (BF) }\end{array}$ & $\begin{array}{c}72 . \text { Slope } \angle \\
\text { (Qmax) }\end{array}$ & $\begin{array}{c}\text { 73. Toe } \\
\text { loc. (BF) }\end{array}$ & $\begin{array}{c}\text { 74. Scour } \\
\text { Condition }\end{array}$ & $\begin{array}{c}75 . \text { Scour } \\
\text { depth }\end{array}$ & $\begin{array}{c}76 . \text { Exposure } \\
\text { depth }\end{array}$ & 77. Material & 78. Length \\
\hline LABUT & & - & $\mathbf{9 0}$ & $\mathbf{2}$ & $\mathbf{1}$ & $\mathbf{1}$ & $\mathbf{1 . 5}$ & $\mathbf{9 0 . 0}$ \\
\hline RABUT & $\mathbf{1}$ & $\mathbf{1 0}$ & $\mathbf{9 0}$ & & & $\mathbf{2}$ & $\mathbf{1}$ & $\mathbf{2 0 . 5}$ \\
\hline
\end{tabular}

Pushed: $L B$ or RB

Toe Location (Loc.): 0- even, 1- set back, 2- protrudes

Scour cond.: 0- not evident; 1- evident (comment); 2- footing exposed; 3-undermined footing; 4- piling exposed; 5- settled; 6- failed

Materials: 1- Concrete; 2- Stone masonry or drywall; 3- steel or metal; 4- wood

79. Abutment comments (eg. undermined penetration, unusual scour processes, debris, etc.):

1

2.5

1

At the middle of the left abutment it is possible to penetrate beneath the footing $0.25 \mathrm{ft}$. At the middle of the right abutment it is possible to penetrate beneath the footing $1.75 \mathrm{ft}$. Some scarring of both abutments and footing faces is evident. The left footing vertical height above the bed is $1.5 \mathrm{ft}$. The right footing is $2.5 \mathrm{ft}$. from the top of footing to the bed at the same point above where the penetration measurement was made. On the US left wingwall and left abutment there is a crack starting at the top and going down 1 foot. There is a large crack 0.25 inches wide running from the bridge seat to the base of the footing on the DS right abutment.

Along the right abutment there is a concrete slab lining the channel from the footing, down 1.5 feet, around to

80. Wingwalls:

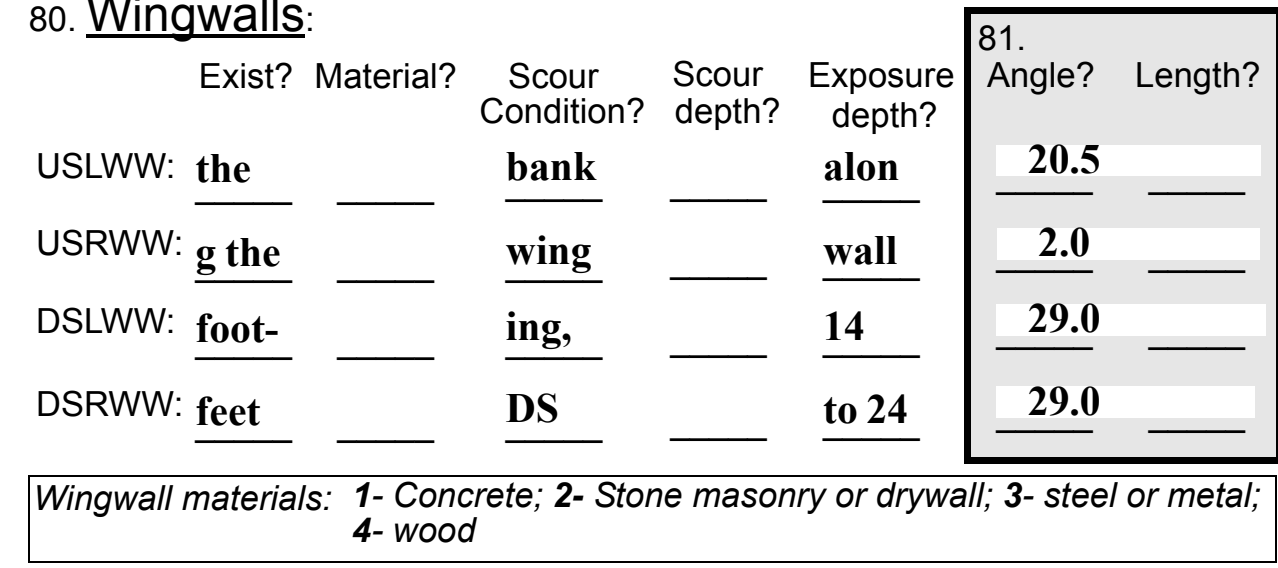

4-wood

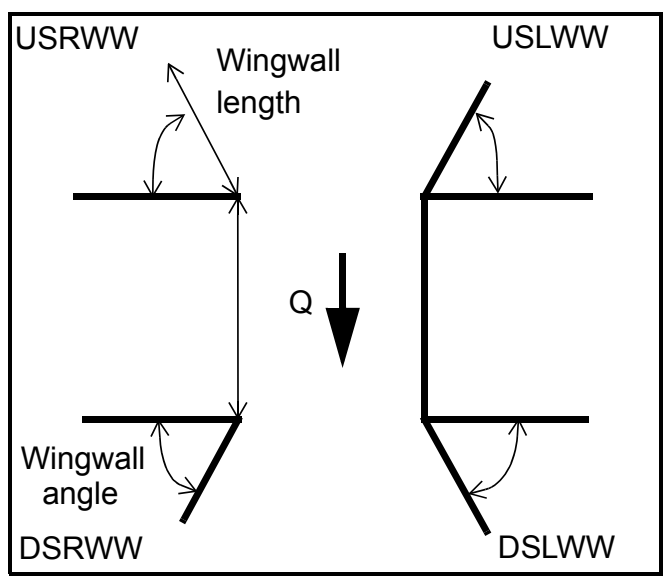

82. Bank / Bridge Protection:

\begin{tabular}{|l|l|l|l|l|l|l|l|l|}
\hline Location & USLWW & USRWW & LABUT & RABUT & LB & RB & DSLWW & DSRWW \\
\hline Type & feet & lweg & US & $\mathbf{- 1}$ & $=$ & DS & $\mathbf{- 1 f t . ~}$ & $\mathbf{1}$ \\
\hline Condition & DS. & $\mathbf{d e p t}$ & $=$ & $\mathbf{f t .}$ & $\mathbf{1 . 5}-$ & $=$ & & $\mathbf{2}$ \\
\hline Extent & Tha & hs: & $\mathbf{0 . 7 5}$ & UB & $\mathbf{2 f t .}$ & $\mathbf{0 . 7 5}$ & Y & $\mathbf{0 . 5}$ \\
\hline
\end{tabular}

Bank / Bridge protection types: 0- absent; 1- < 12 inches; 2- < 36 inches; 3- < 48 inches; 4- < 60 inches; 
83. Wingwall and protection comments (eg. undermined penetration, unusual scour processes, etc.):

1.5

Y

1

2

0.33

1.33

Y

1

2

0.5

1.5

\section{Piers:}

84. Are there piers? $\quad \mathbf{Y}$ (Y or if $N$ type ctrl-n pr)

\begin{tabular}{|l|r|r|r|r|l|l|l|}
\hline \multirow{2}{*}{$\begin{array}{l}85 . \\
\text { Pier no. }\end{array}$} & \multicolumn{3}{|c|}{ width (w) feet } & \multicolumn{5}{c|}{ elevation (e) feet } \\
\cline { 2 - 8 } & w1 & w2 & w3 & e@w1 & e@w2 & e@w3 \\
\hline Pier 1 & & & & $\mathbf{2 0 . 0}$ & $\mathbf{1 5 . 0}$ & $\mathbf{9 0 . 0}$ \\
\hline Pier 2 & $\mathbf{9 . 5}$ & $\mathbf{8 . 0}$ & & $\mathbf{3 5 . 0}$ & $\mathbf{1 5 . 0}$ & $\mathbf{1 5 . 0}$ \\
\hline Pier 3 & - & - & - & - & - & - \\
\hline Pier 4 & - & - & - & - & - & - \\
-
\end{tabular}

\begin{tabular}{|l|l|l|l|l|}
\hline Level 1 Pier Descr. & \multicolumn{1}{|c|}{1} & \multicolumn{1}{|c|}{2} & \multicolumn{1}{|c|}{4} & \multicolumn{1}{|c|}{} \\
\hline 86. Location (BF) & $\mathbf{1}$ & - & $\mathbf{1}$ & with \\
\hline 87. Type & $\mathbf{2}$ & $\mathbf{1}$ & $\mathbf{1}$ & cob- \\
\hline 88. Material & $\mathbf{0 . 7 5}$ & $\mathbf{1}$ & $\mathbf{1}$ & bles \\
\hline 89. Shape & $\mathbf{1 . 7 5}$ & $\mathbf{3}$ & $\mathbf{1}$ & and \\
\hline 90. Inclined? & $\mathbf{2}$ & $\mathbf{0}$ & All & smal \\
\hline 91. Attack $\angle$ (BF) & $\mathbf{1}$ & - & four & 1 \\
\hline 92. Pushed & $\mathbf{1}$ & - & wing & boul- \\
\hline 93. Length (feet) & - & - & - & - \\
\hline 94. \# of piles & $\mathbf{2}$ & $\mathbf{0}$ & walls & ders. \\
\hline 95. Cross-members & $\mathbf{2}$ & - & have & It is \\
\hline 96. Scour Condition & $\mathbf{2}$ & - & been & most \\
\hline 97. Scour depth & $\mathbf{0}$ & $\mathbf{2}$ & back & evi- \\
\hline 98. Exposure depth & - & $\mathbf{2}$ & filled & dent \\
\hline
\end{tabular}

LFP, LTB, LB, MCL, MCM, MCR, RB, RTB, RFP

1- Solid pier, 2- column, 3- bent

1- Wood; 2- concrete; 3- metal; 4- stone

1- Round; 2- Square; 3- Pointed

Y-yes; $N$ - no

$L B$ or $R B$

0- none; 1- laterals; 2- diagonals; 3- both

0- not evident; 1- evident (comment);

2- footing exposed; 3- piling exposed;

4- undermined footing; 5- settled; 6-failed 
99. Pier comments (eg. undermined penetration, protection and protection extent, unusual scour processes, etc.):

at the US wingwalls. There is damage to the US left wingwall and concrete face above the steel. The edge of the concrete above the steel is chopped and scarred. The wingwall has a large scarred area approximately 1 ft. by $3 \mathrm{ft}$. wide just below the girder level. Similar damage is observed on the downstream left wingwall. It is possible to penetrate the US left wingwall approximately 3 inches where the wingwall and abutment meet.

100.

\section{E. Downstream Channel Assessment}

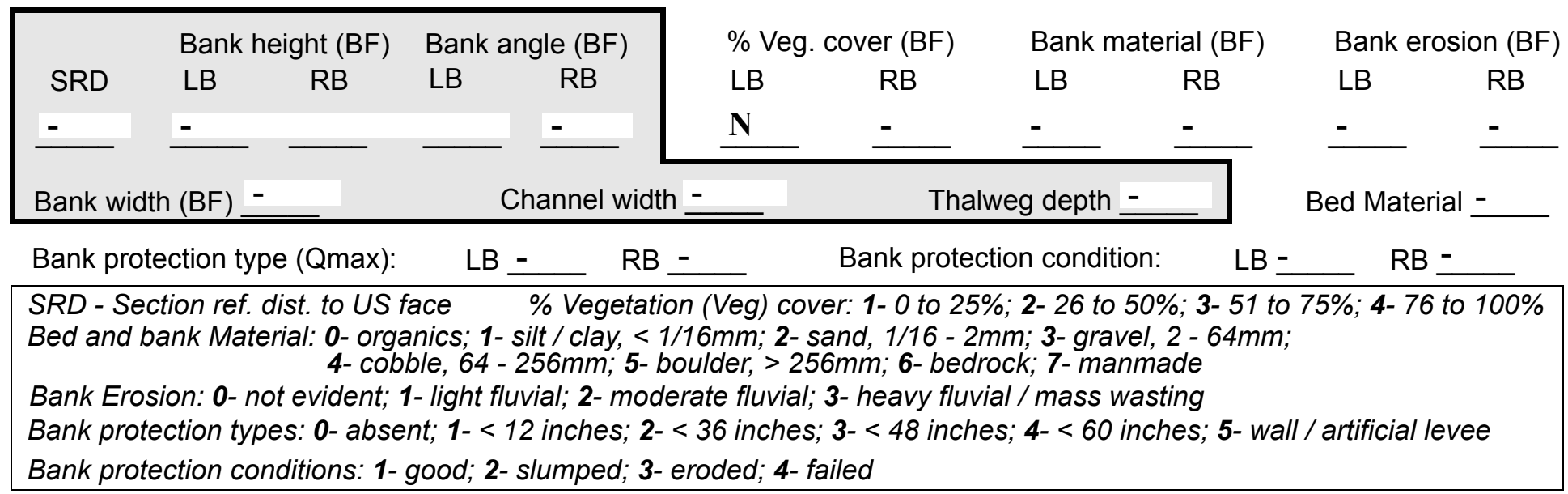

Comments (eg. bank material variation, minor inflows, protection extent, etc.):$$
-
$$

$-$

-

-

-

$-$

-

-

-

$-$

\section{Is a drop structure present? __ ( $Y$ or $N$, if $N$ type ctrl-n $d s) \quad$ 102. Distance: ___ feet}
103. Drop: - feet
104. Structure material: -
(1- steel sheet pile; 2- wood pile; 3- concrete; 4- other)

105. Drop structure comments (eg. downstream scour depth): 
106. Point/Side bar present? (Y or $N$. if $N$ type ctrl-n pb)Mid-bar distance:

Mid-bar width: -

Point bar extent: feet -

(US, UB, DS) to feet (US, UB, DS) positioned \%LB to $\%$ RB Material:

Point or side bar comments (Circle Point or Side; note additional bars, material variation, status, etc.):

$-$

$-$

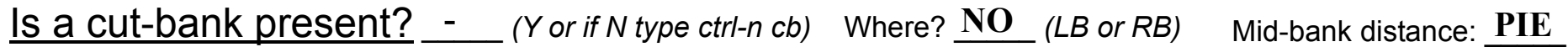
Cut bank extent: $\underline{\mathbf{R S}}$ feet __ (US, UB, DS) to feet ___ (US, UB, DS)

Bank damage: (1- eroded and/or creep; 2- slip failure; 3- block failure)

Cut bank comments (eg. additional cut banks, protection condition, etc.):

Is channel scour present? Scour dimensions: Length $\underline{3}$ Width 34 (Y or if $N$ type ctrl-n cs)

Mid-scour distance: $\underline{\mathbf{3}}$

Scour comments (eg. additional scour areas, local scouring process, etc.): 543

$\mathbf{0}$

0

Are there major confluences? Confluence 1: Distance Enters on ( $L B$ or $R B)$ How many? -

Confluence 2: Distance Enters on (LB or $R B)$

Positioned 1 $\%$ LB to 1 $\% \mathrm{RB}$

\section{F. Geomorphic Channel Assessment}

107. Stage of reach evolution
1- Constructed

2- Stable

3- Aggraded

4- Degraded

5- Laterally unstable

6- Vertically and laterally unstable 
108. Evolution comments (Channel evolution not considering bridge effects; See HEC-20, Figure 1 for geomorphic descriptors):

$\mathbf{N}$

$-$

NO DROP STRUCTURE 


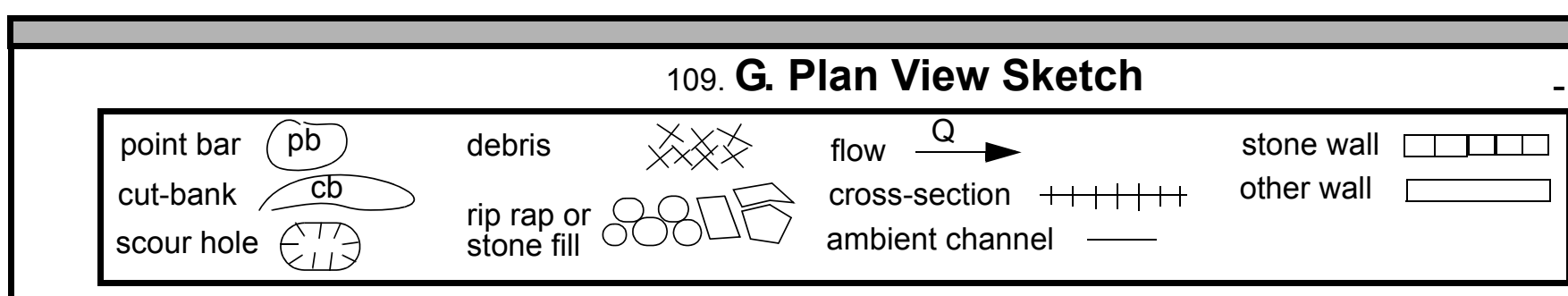


APPENDIX F:

SCOUR COMPUTATIONS 


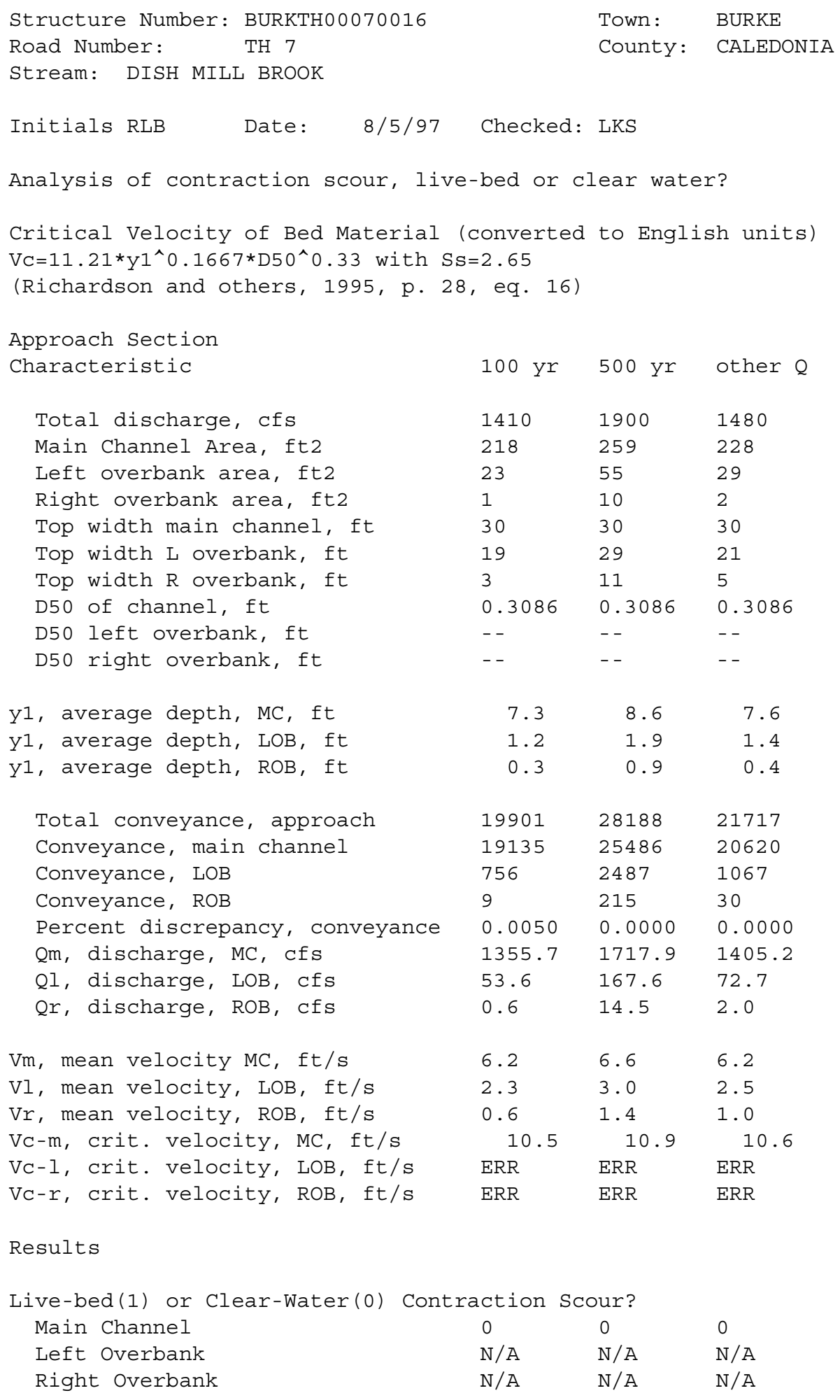


Clear water Contraction Scour in MAIN CHANNEL

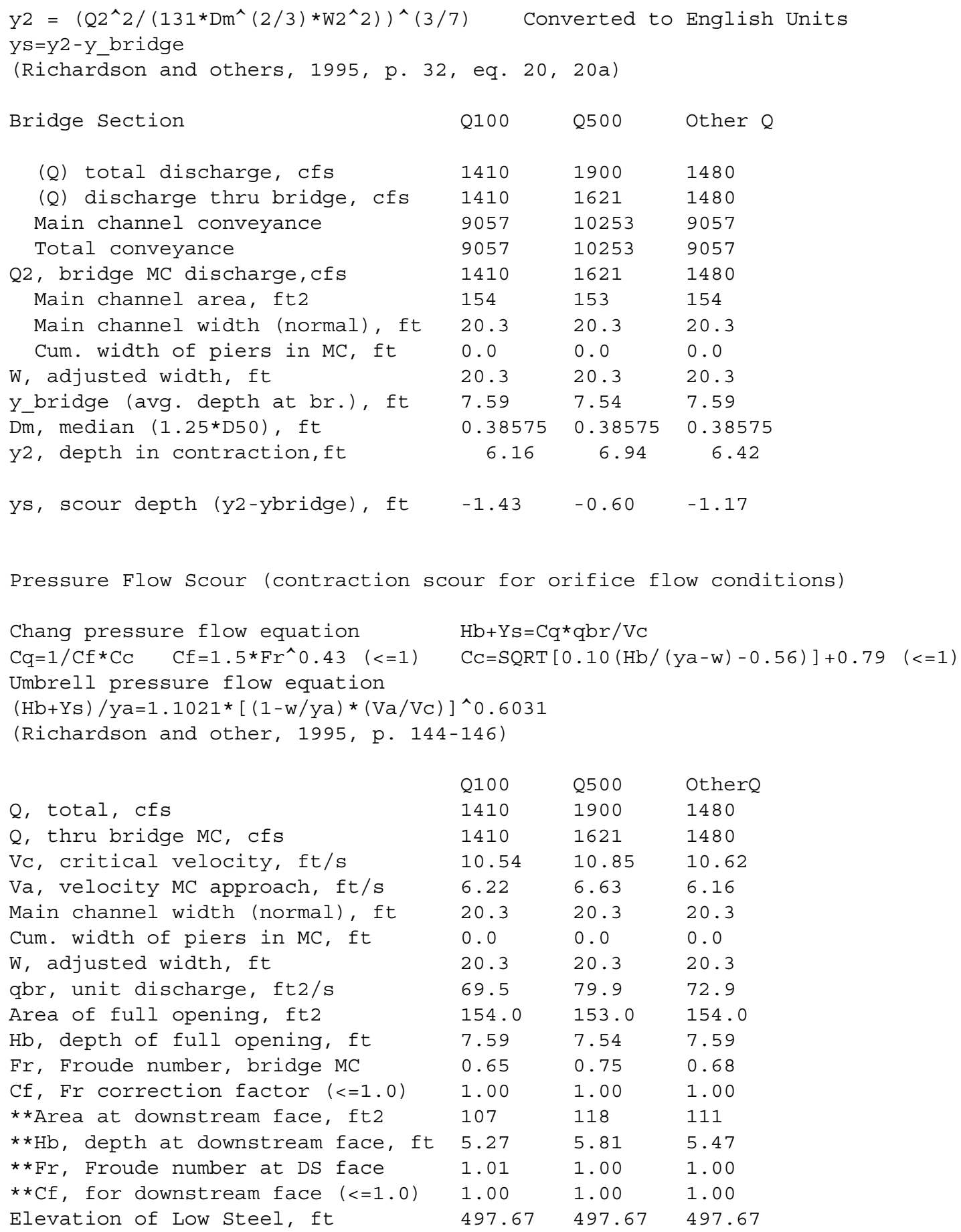




\begin{tabular}{|c|c|c|c|}
\hline Elevation of Bed, ft & 490.08 & 490.13 & 490.08 \\
\hline Elevation of Approach, ft & 499.85 & 501.2 & 500.18 \\
\hline Friction loss, approach, ft & 0.17 & 0.16 & 0.17 \\
\hline Elevation of WS immediately US, ft & 499.68 & 501.04 & 500.01 \\
\hline ya, depth immediately US, ft & 9.60 & 10.91 & 9.93 \\
\hline Mean elevation of deck, ft & 500.78 & 500.78 & 500.78 \\
\hline w, depth of overflow, ft $(>=0)$ & 0.00 & 0.26 & 0.00 \\
\hline Cc, vert contrac correction $(<=1.0)$ & 0.94 & 0.91 & 0.93 \\
\hline$* * \mathrm{CC}_{\mathrm{C}}$, for downstream face $(<=1.0)$ & 0.79 & 0.79 & 0.79 \\
\hline Ys, scour w/Chang equation, ft & -0.59 & 0.54 & -0.23 \\
\hline Ys, scour w/Umbrell equation, ft & 0.11 & 1.27 & 0.29 \\
\hline \multicolumn{4}{|c|}{ **=for UNsubmerged orifice flow using estimated downstream bridge face } \\
\hline **Ys, scour w/Chang equation, ft & 3.07 & 3.50 & 3.22 \\
\hline **Ys, scour w/Umbrell equation, ft & 2.42 & 2.99 & 2.41 \\
\hline \multicolumn{4}{|c|}{$\begin{array}{l}\text { In UNsubmerged orifice flow, an adjusted scour depth using the Laursen } \\
\text { equation results and the estimated downstream bridge face properties } \\
\text { can also be computed (ys=y2-ybridgeDs) }\end{array}$} \\
\hline y2, from Laursen's equation, ft & 6.16 & 6.94 & 6.42 \\
\hline WSEL at downstream face, ft & 495.36 & 495.89 & 495.53 \\
\hline Depth at downstream face, ft & 5.27 & 5.81 & 5.47 \\
\hline Ys, depth of scour (Laursen), ft & 0.89 & 1.13 & 0.95 \\
\hline
\end{tabular}

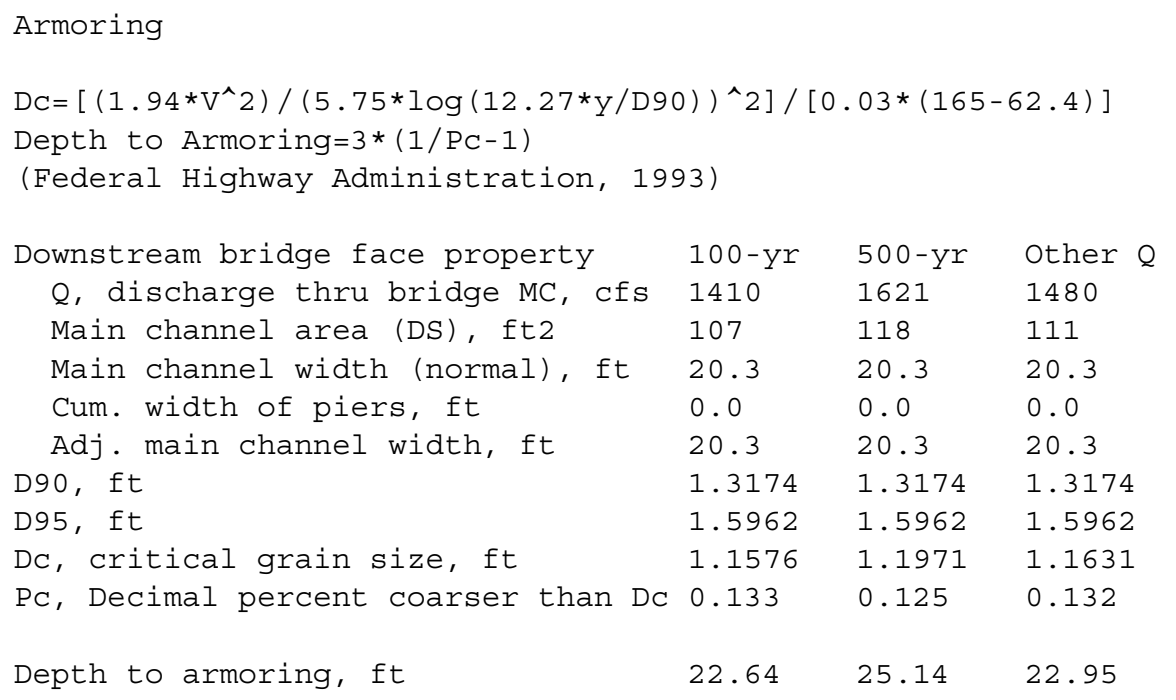

Abutment scour

Froehlich's Abutment Scour

$\mathrm{Ys} / \mathrm{Y} 1=2.27 * \mathrm{~K} 1 * \mathrm{~K} 2 *\left(\mathrm{a}^{\prime} / \mathrm{Y} 1\right) \wedge 0.43 * \mathrm{Fr} 1 \wedge 0.61+1$

(Richardson and others, 1995, p. 48, eq. 28)

\begin{tabular}{|c|c|c|c|c|c|c|}
\hline \multirow[b]{2}{*}{ Characteristic } & \multicolumn{2}{|c|}{ Left Abutment } & \multicolumn{4}{|c|}{ Right Abutment } \\
\hline & $100 \mathrm{yr}$ & $00 \mathrm{y} r$ & ther $\mathrm{Q}$ & $00 \mathrm{yr}$ & $00 \mathrm{yr}$ & ther $Q$ \\
\hline (Qt), total discharge, cfs & 1410 & 1900 & 1480 & 1410 & 1900 & 1480 \\
\hline a', abut.length blocking flow, ft & 22.9 & 33.5 & 25.5 & 9.2 & 16.5 & 11 \\
\hline Ae, area of blocked flow ft 2 & 45.54 & 73.89 & 53.74 & 25.93 & 29.26 & 28.87 \\
\hline
\end{tabular}




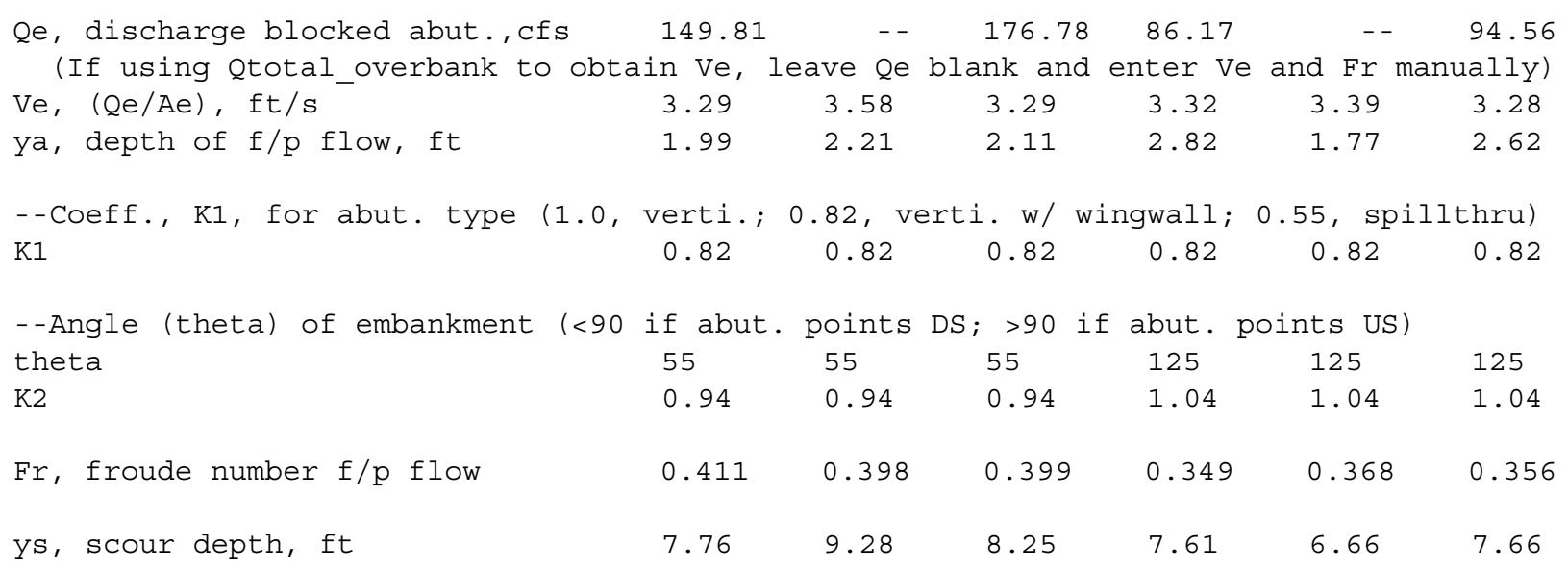

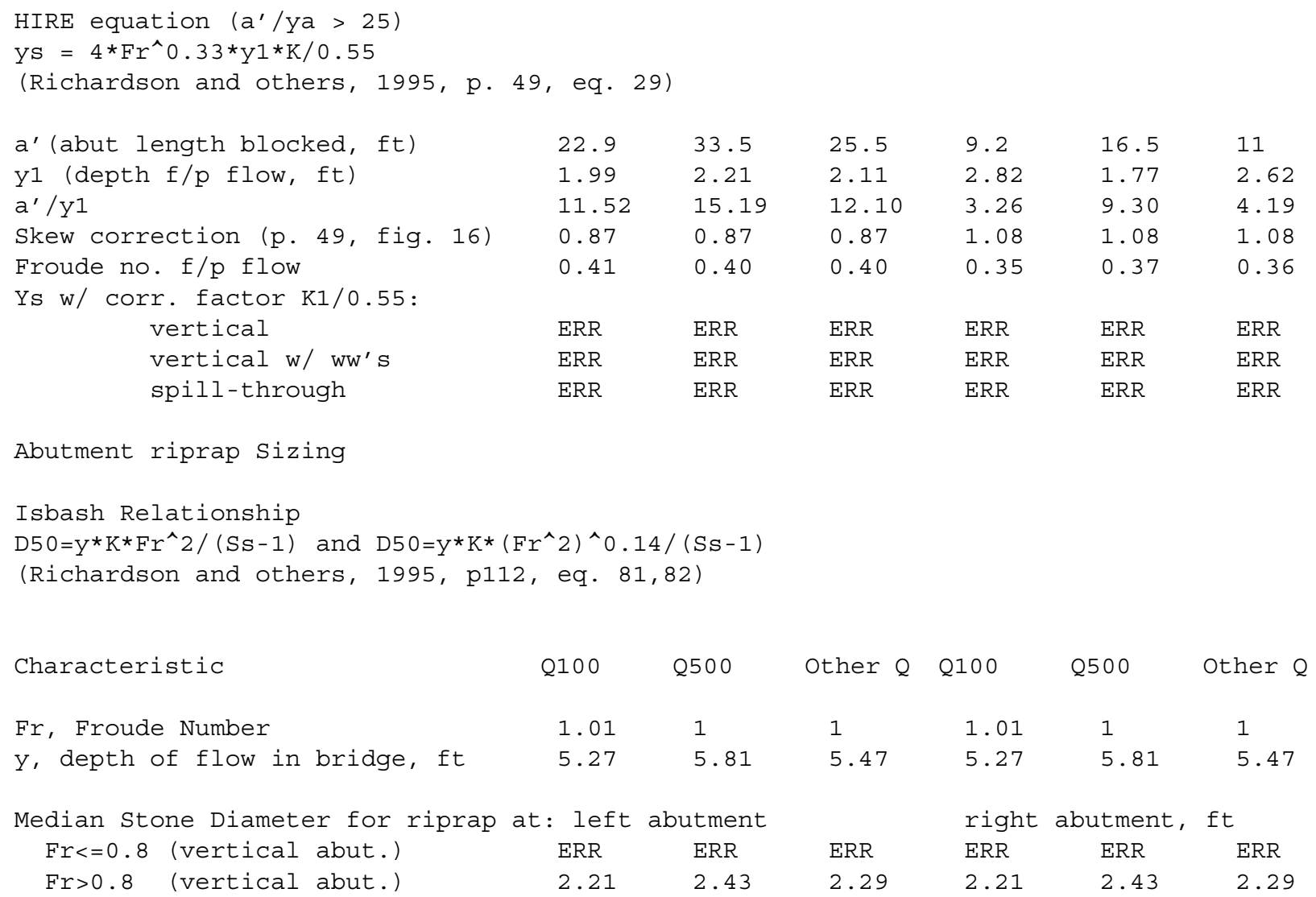


